\title{
CHINA'S APOLOGETIC JUSTICE: LESSONS FOR THE UNITED STATES?
}

\author{
XUAN-ThaO NGUYEN*
}

\begin{abstract}
Many scholars have criticized Congressional apology resolutions for slavery as inadequate and ineffective. Ironically, Congress may look to China's apologetic justice in intentional intellectual property infringements to learn valuable lessons about apologies and how to incorporate them into righting wrongs. China requires that the wrongdoer who intentionally harms or infringes the intellectual property rights of another make a public apology in a newspaper or trade journal, in addition to stopping the harm and paying for compensatory damages and costs. If the wrongdoer does not timely make the public apology, the infringed party will draft and publish the public apology in the wrongdoer's name and charge the associated expenses to the wrongdoer. Again, the public apology is in addition to, not in lieu of, injunctive relief and damages. If Congress approaches apology resolutions to slavery in a similar way to what China has done for remedies in intentional intellectual property infringements, Congress will adequately address scholars' criticisms.
\end{abstract}

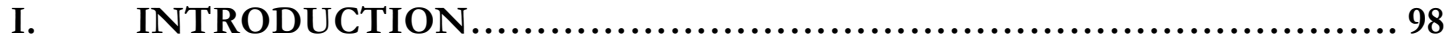

II. CONGRESS'S APOLOGY TO SLAVERY .............................. 101

A. Apology and Recent Scholarship on Slavery Redress ............... 101

B. Congress's Apologetic Statements ............................ 103

III. CHINA AND PUBLIC APOLOGIES IN INTELLECTUAL PROPERTY

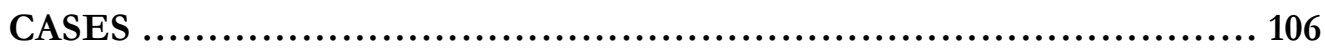

A. China's Intellectual Property Law ............................ 106

B. The Chinese Court's Decisions in Intellectual Property Cases ...... 113

1. Zhang Linying and Other Three Persons v. Guangyuan Co. Ltd., Chinese Revolutionary Museum and Gongmei Corp. Group .................................................... 113

* Gerald L. Bepko Endowed Chair in Law, Director of the Center for Intellectual Property and Innovation, Indiana University McKinney School of Law; Former IP Associate, Fried Frank Harris Shriver \& Jacobson (NYC) and Pryor Cashman Sherman \& Flynn (NYC). A version of this article was presented at the Howard University School of Law Symposium on Civil Rights and Intellectual Property. Many thanks to all of my friends and colleagues in the United States and China for their contributions to this article. This article is part of a series of articles on comparative scholarship relating to Chinese Intellectual Property Remedies. Thanks to Pei-Chih H. Keene, Sara Alyn Horner, and Tiffany Lunney for providing valuable research assistance. Special thanks to Erik Darwin Hille and Khai-Leif NguyenHille for their love, patience and support. Copyright 2014 by Professor Xuan-Thao Nguyen. 
2. Golden Human Computer Co. Ltd v. HST Scientific and Technological Development Center ............................. 114

3. Starbucks Corporation and Shanghai President Coffee Corporation v. Shanghai Starbucks Café Company Limited and Shanghai Starbucks Café Company Limited, Nanjing Road Branch

4. Zhang Chengzhi v. 21 ViaNet Communications Technology Co., Ltd.

5. Beijing Baidu Netcom Science and Technology Co., Ltd. v. Tsingtao Osun Network Technique Co., Ltd., et. Al.

IV. APOLOGY CONTEXT, CONTENT, AND PURPOSE

A. In Newspapers or Trade Publications

B. Recognition of the Injured Person's Rights 124

C. Admission of Wrongs 124

D. Cease the Infringing Conduct 125

E. Apologize and Promise Not to Engage in Future Infringement .... 125

F. Apologies as Part of Remedies ............................... 125

V. FROM CHINA WITH MEANINGFUL APOLOGIES: IN ADDITION TO DAMAGES AND INJUNCTION 126

VI. WHAT CONGRESS CAN LEARN FROM CHINA ABOUT MEANINGFUL APOLOGIES 127

VII. CONCLUSION 128

\section{INTRODUCTION}

The recent visit by the President of the People's Republic of China, Xi Jinping, was an opportunity for the United States Congress to express its contempt for the copious violations of U.S. intellectual property rights by Chinese individuals and companies. ${ }^{1}$ Perhaps, instead of unilaterally criticizing China for intellectual property theft and piracy, Congress should take a respite and look to China for some insights. Paradoxically, China's Intellectual Property law may offer a lesson for Congress to learn in regard to apologizing for slavery.

\footnotetext{
${ }^{1}$ See generally Jonathan Weisman, U.S. to Share Cautionary Tale of Trade Secret Theft With Chinese Official, N.Y. TIMES Feb. 14, 2012, at A10, http://www.nytimes.com/2012/02/15/world/asia/chinese-official-to-hear-trade-thefttale.html?_r=1. (see R16.6(f))
} 
Congress, in its separate chambers, passed resolutions apologizing for slavery. ${ }^{2}$ As noted by scholars, the apology was inadequate and ineffective. The apology included a disclaimer that served to disallow any attempt to use the apology to support any reparation claims. ${ }^{3}$ It did not accompany any programs to address past historic harms caused by slavery or Jim Crow. Further, neither the House nor the Senate disseminated or publicized its apology in any newspapers throughout the United States. The public hardly knew the existence of each chamber's apology.

Looking across the Pacific, Congress may learn how an apology can be meaningful in addressing wrongs. Specifically, under China's Intellectual Property law, when a person is injured due to intentional infringement of the person's name, trademark or copyright, the wrongdoer must cease the wrongful conduct and pay the injured person for either economic losses incurred by the injured person or the economic gains wrongfully accumulated by the wrongdoer. In addition, the wrongdoer in these cases must make a public apology to the injured person in a newspaper or trade publication. The apology is meaningful for several reasons: (1) the apology is both remorseful and purposeful in its content addressing the wrongs, (2) the apology is public and accessible since it is published in a daily newspaper or trade publication for the public to read, and (3) the apology is accompanied by both injunctive relief and monetary damages.

It is undeniable that the redress question on slavery is a very complex matter. Countless scholars, especially African-American scholars and activists, have devoted much effort over many of the past decades to lead the redress movement inside and outside the academy. ${ }^{4}$ This Article acknowledges the profound works many scholars have generated and contributed towards legal and policy solutions to address the legacy of U.S. slavery. This Article will not repeat and recite the valuable and voluminous scholarship on the legacy of slavery or reparations. Instead, this Article attempts to stretch outside U.S. boundaries for insights on addressing wrongs through meaningful apologies. China unexpectedly offers a new vista for thought.

Part I of this Article surveys the most recent scholarship on slavery redress. It highlights recent scholarship in which apologies have been discussed as part of racial reconciliation. Most scholars seem to agree that an apology alone cannot heal the horrific harms that were inflicted. Atonement can only be achieved with a combination of apology and reparations. Some scholars suggest apology, plus monetary compensation and nonrepetition methods. Others argue for apology along with a thorough study of past injustice or specific constructions of sites and activities dedicated to educating the public about slavery. Meaningful apologies for historic wrongs require apology-plus. ${ }^{5}$

2 See H. R. Res. 194, 110th Cong. (2008), available at http://thomas.loc.gov/home/gpoxmlc110/hr194_eh.xml; S. Con. Res. 26, 111th Cong. (1st Sess. 2009), available at http://www.govtrack.us/congress/bills/111/sconres26/text (the Senate passed its resolution and referred it to House Committee on June 18, 2009, but the House never voted on the resolution. See A Concurrent Resolution Apologizing for the Enslavement and Racial Segregation of African Americans, GOVTRACK.US, http://www.govtrack.us/congress/bills/111/sconres26 (last visited May 17, 2014) (tracking the status of the resolution).

${ }^{3}$ Krissah Thompson, Senate Unanimously Approves Resolution Apologizing for Slavery, THE WASHINGTON POST (June 19, 2009), http://www.washingtonpost.com/wp-dyn/content/article/2009/06/18/AR2009061803877.html (reporting that scholars and activists like Charles Olgetree and Randall Robinson have asserted that the apology is not a substitution for restitution or reparation); Yvonne R. Davis, The US Senate Apologized for Slavery. But We Ain't Gettin' 40 Acres and a Mule!, The Huffington POST Blog (June 19, 2009, 1:53 PM), http://www.huffingtonpost.com/yvonne-rdavis/the-us-senate-apologized_b_217753.html (explaining that apology is meaningful if it comes with monetary payment).

4 See infra Part II.A.

5 See infra Part II.A. 
This important scholarship has contributed to the policy debate on slavery redress and Congress's apologies for slavery. Part II analyzes, compares, and contrasts the apology statements passed by each chamber of Congress. Most importantly, Congress's apologies, which were merely written apologies, will be compared to the apology-plus that scholars have argued for. ${ }^{6}$

Searching beyond U.S. boundaries, Part III voyages into Chinese Intellectual Property law. Remedies in Chinese Intellectual Property law provide an apology-plus model. Under the Chinese Civil Code, Trademark statute, Copyright statute, and Anti-Unfair Competition statute, courts issue injunctions against the wrongdoer and order the wrongdoer to make payments in the form of compensation or accounting of profits. In addition, courts instruct the wrongdoer to make a public apology in a newspaper or trade publication to eliminate any ill effects from the wrongdoer's conduct. The content of the apology must be pre-approved by the court prior to publication. If the wrongdoer fails to comply, the court will allow the injured party to publish the apology statement and charge the wrongdoer with the associated cost. Part III.B studies five written decisions issued by courts in different parts of China concerning intentional acts of intellectual property infringement wherein apologies are part of the remedies. ${ }^{7}$

What does an apology look like under Chinese law? Part IV focuses on the content and context of apologies published in Chinese newspapers or trade publications. A careful analysis of the apologies reveals that they share certain characteristics. They are widely accessible for the public to read. They are purposeful as they recognize the injured party's rights, admit the wrongdoing, cease the infringing conduct, apologize, and promise not to engage in future infringement. ${ }^{8}$

Part V suggests that Congress can learn about meaningful apologies from China. The characteristics, content, and context of public apologies in Chinese intellectual property cases are valuable lessons for Congress to ponder, beyond the typical criticism of China as "The Other," a nation known mostly for intellectual property theft problems. Meaningful apologies require apology-plus. The apology must be public and widely disseminated. The apology must be in addition to injunctions and damages. That means the wrongdoer makes payment to the injured person, and will only make a public apology if the wrongs are intentional and harmful to both the wrongdoer and the public. ${ }^{10}$

Congress might dismiss China and its approach to meaningful apologies as confined to intellectual property law and frame the legacy of slavery as being "too big to apologize" meaningfully. Congress might ignore any discussion on monetary reparation, studies of slavery injustice, construction of memorials and monuments, and programs to educate the public about slavery. The Article concludes that it is certainly easier to continue tirades about China to gain some points in opinion polls. The problem remains. Congress's apology statements ring hollow. ${ }^{11}$

\footnotetext{
6 See infra Part II.B.

7 See infra Part III.

8 See infra Part IV.

${ }^{9}$ For a theoretical understanding and elaboration of the construction of "the other" through social and political processes of “othering”, see generally EDWARD SAID, ORIENTALISM (1st ed., Vintage Books 1979) (1978).

10 See infra Part V.

11 Congress has done a better job in addressing the historic wrongs of interning Japanese-Americans during World War II. See generally InJustiCE AND RECTIFICATION 17 (Rodney C. Roberts ed., 2005). The Civil Liberties Act of 1988 includes an apology from both President Ronald Reagan and the United States Congress for the internment of Japanese-Americans during World War II. The public apology was accompanied by $\$ 20,000$ per victim for their losses and suffering. See Civil Liberties Act of 1988, Pub. L. No. 100-383, 102 Stat. 904 (1988). For in-depth discussions on reparation to Japanese Americans for their internments, see generally Eric K. Yamamoto \& Liann Ebesugawa, Report on
} 


\section{CONGRESS'S APOLOGY TO SLAVERY}

As well-documented elsewhere, attempts to redress the harms of slavery have come in waves, dating back at least to the 1860's. ${ }^{12}$ Thoughtful scholarship on slavery redress provides a theoretical framework for addressing historic wrongs. Activism, both inside and outside academia, led in part to Congress issuing apology statements for slavery.

\section{A. Apology and Recent Scholarship on Slavery Redress}

To seek redress for the horrific harms suffered by enslaved African-Americans and their descendants, reparation activists have brought lawsuits alleging tort and unjust enrichment claims. ${ }^{13}$ They demand compensation for the unpaid labor that slaves performed and refund of the benefits the United States unjustly gained from slavery. ${ }^{14}$ In addition to litigation, scholars have developed a significant and important body of thoughtful scholarship to explore and examine the harms slavery inflicted on AfricanAmericans and to propose different models to redress these harms. ${ }^{15}$

Illustratively, in contemporary reparations scholarship, Professor Roy Brooks's influential work, Atonement and Forgiveness, emphasizes both apology and monetary reparation in a forward-looking racial reconciliation approach. ${ }^{16}$ Righting wrongs requires the U.S. government to issue acknowledgments of

Redress: The Japanese American Internment, in THE HANDBOOK OF REPARATIONS 257-83 (Pablo De Greiff ed., 2006); ERIC K. YAmAmoto ET AL., RACE, Rights, AND REPARATION: LAW OF THE JAPANESE AMERICAN INTERNMENT $390-406$ (2001); Mitchell T. Maki, Harry H.L. Kitano \& S. Megan Berthold, ACHieving the Impossible Dream: How JAPANESE AMERICANS OBTAINED REDRESS (1999).

12 See also Maxine Burkett, Reconciliation and Non-Repetition: A New Paradigm for African American Reparations, 86 OR. L. REV. 99, 106-110 (2007) (providing a brief history of four major waves of reparations activism).

13 See also Kaimipono David Wenger, Too Big to Remedy? Rethinking Mass Restitution for Slavery and Jim Crow, 44 LOY. L.A. L. REV. 177, 188-191 (2010) (summary of three lawsuits, Cato v. United States, 70 F.3d 1103 (9th Cir. 1995); In re African-American Slave Descendants Litigation, 375 F. Supp. 2 d 721 (N.D. Ill. 2005); and Alexander v. Oklahoma, 382 F.3d 1026 (10th Cir. 2004). See generally Alfred L. Brophy, Reparations Talk: Reparations for Slavery and the Tort Law Analogy, 24 B.C. THIRD WORLD L.J. 81, 123-27 (2004) (devising tort-based claims and unjust enrichment arguments to remedying the evils of slavery).

14 See generally Charles J. Ogletree Jr., Chapter 17 Addressing the Racial Divide: Reparations, 20 HARV. BLACKLETTER L.J. 115 (2004); Alfred L. Brophy, Reparations: Pro \& CON 11 (2006) (surveying the debates, litigations, and arguments on reparations).

15 Roy L. Brooks, Getting Reparations for Slavery Right: A Response to Posner and Vermeule, 80 NOTRE DAME L. REV. 251, 272-87 (2004) (providing an overview of two dominant models, atonement and tort, for redress). The tort, litigation or settlement model seeks monetary compensation for the injured. This model is not concerned so much with apology, but with settling dispute. $I d$. at 285. Professor Brooks noted that in recent years, however, the proponents for the tort model, such as Professors Charles Ogletree and Randall Robinson, have moved closer to the atonement model. Id. at 285 n. 171; Alfred L. Brophy, Reconsidering Reparations, 81 IND. L.J. 811, 842 (2006) (advocating a community-based welfare model to evaluating the morality and utility of reparations). See also RANDALL RoBINSON, THE DEBT: WHAT AMERICA OWES TO BLACKS (2001) (detailing comprehensive reparation programs to address slavery as well as the social and economic issues suffered by African-Americans); Charles P. Henry, LOng Overdue: The POlitics Of RACIAL ReParations (2007) (detailing case studies of reparations); Rhonda v. Magee, The Master's Tools, From the Bottom Up: Responses to African-American Reparations Theory in Mainstream and Outsider Remedies Discourse, 79 VA. L. REV. 863,914 (1993) (advocating that among "integration, separation and reparations, only the last simultaneously acknowledges official responsibility, promotes economic and cultural self-sufficiency, and relinquishes to African-Americans a measure of control over the implementation of the remedy").

16 Roy L. Brooks, Atonement and Forgiveness: A New Model for Black Reparations 142 (2004). For additional readings on redressing slavery harms, see generally Roy L. Brooks, Toward a Perpetrator-Focused Model of Slave Redress, 6 AFR.-AM. L. \& POL'Y REP. 49 (2004); Kevin Hopkins, Forgive U.S. Our Debts? Righting the Wrongs of Slavery, 89 GEO. L.J. 2531 (2001); Alfreda Robinson, Corporate Social Responsibility and African American Reparations: Jubilee, 55 Rutgers L. REV. 309, 358-84 (2003); Paige A. Fogarty, Speculating a Strategy: Suing Insurance Companies to Obtain Legislative Reparations for Slavery, 9 ConN. INS. L.J. 211, 224-41 (2002); Donald Aquinas Lancaster, Jr., The Alchemy and Legacy of the 
the atrocity, make an admission of wrongful conduct, and apologize to the injured. ${ }^{17}$ The moral obligation to apologize, however, would ring hollow if the apology is not accompanied by concrete, tangible measures of reparation. ${ }^{18}$

Professor Alfred Brophy thoroughly examined the pros and cons of reparations in his book and offers that apologies can be "part of a meaningful program of repair and reconciliation."19 The harms inflicted by historic wrongs may be "best repaired" by a study of past injustices and by apologies. ${ }^{20}$ The apology, Professor Brophy emphasizes, must be sincere in order for it to be valuable and meaningful. ${ }^{21}$

Other scholars like Professor Maxine Burkett, argue that among the three essential elements of redressing slavery—apology, monetary compensation, and nonrepetition through reconciliation—the last element is the most important component for a successful reparations campaign. ${ }^{22}$ The nonrepetition method aims to "challenge and dismantle the attitudes or infrastructures from which wrongful acts emerged" and therefore deter future bad acts, resulting in "ultimate, complete, and successful repair." 23 The model requires multiracial, multiethnic, and cross-class reconciliation to ensure nonrepetition. ${ }^{24}$

Likewise, Professor Carlton Walterhouse analyzed rectificatory justice theory and advocated for a "collective memory of slavery within all Americans" 25 through the creation of memorials, museums, commemorations, and education and research grants related to slavery. ${ }^{26}$ Walterhouse recognized that such steps should come after an apology is made by a joint resolution of Congress and signed by the President. ${ }^{27}$

In summary, in the already robust and continuously growing scholarship on slavery redress, apology is an important part of racial reconciliation. Most scholars seem to agree that apology alone cannot heal the horrific harms. Some believe that atonement can only be achieved with both apology and reparations. Some want an apology plus monetary compensation and nonrepetition methods. Others seek apology with a thorough study of past injustice. Others advocate for apology and the specific

United States of America's Sanction of Slavery and Segregation: A Property Law and Equitable Remedy Analysis of African American Reparations, 43 How. L.J. 171 (2000); Vincene Verdun, If the Shoe Fits, Wear It: An Analysis of Reparations to African Americans, 67 TUL. L. REV. 597 (1993).

${ }_{17}$ Brooks, ATONEMENT, supra note 16, at 144.

${ }^{18}$ Id. at ix (Professor Brooks explains what "atonement" means:

When a government commits an atrocity against an innocent people, it has, at the very least, a moral obligation to apologize and to make that apology believable by doing something tangible called a "reparation." The government of the United States committed atrocities against black Americans for two and one-quarter centuries in the form of chattel slavery and for an additional one hundred years in the form of Jim Crow-what Supreme Court Justices Ruth Bader Ginsburg and Stephen Breyer refer to as "a law-enforced racial caste system"-and it has not even tendered an apology for either. The U.S. government should, in fact, atone-that is, both apologize and provide reparations - for racial slavery and apartheid. Saying "I'm sorry" just isn't enough.)

${ }^{19}$ Brophy, supra note 14 , at 11.

${ }^{20} \mathrm{Id}$.

${ }^{21} \mathrm{Id}$.

22 See Burkett, supra note 12.

${ }^{23}$ Id. at 99.

${ }^{24}$ Id. at 100 .

25 Carlton Walterhouse, Total Recall: Restoring the Public Memory of Enslaved African-Americans and the American System of Slavery Through Rectificatory Justice and Reparations, 14 J. GENDER RACE \& JUST. 703, 745 (2011) (concluding what must be done to address the harms to African-Americans).

26 See id. at 739-40 (explaining the two-steps approach to redress).

27 See id. at 740 (discussing how commemoration would reshape America's collective memories of slavery beyond the museum space). 
construction of sites and activities dedicated to educating the public about slavery. In other words, meaningful apologies for historic wrongs require apology-plus.

\section{B. Congress's Apologetic Statements}

After facing years of pressure on slavery redress, both chambers of Congress separately issued apology statements. On July 29, 2008, the House of Representatives passed House Resolution 194 to apologize for slavery and Jim Crow. ${ }^{28}$

The House Resolution contains seventeen "whereas" clauses which detail the horrors of slavery from 1619 through 1865, when Africans were "captured and sold at auction like inanimate objects or animals," and "brutalized, humiliated, dehumanized" under the legal slavery system. ${ }^{29}$ Though 246 years of legal slavery ended, ${ }^{30}$ racial segregation laws and the Jim Crow system continued until the 1960's. ${ }^{31}$ The vestiges of slavery, however, "still linger" today. Two "whereas" clauses mention that President George W. Bush "acknowledged slavery's continuing legacy in American life and the need to confront that legacy" 32 and President Bill Clinton "acknowledged the deep-seated problems" caused by the continuing legacy of racism that began with slavery and "initiated a national dialogue about race." 33

The House Resolution recognized that it is important for the United States to "make a formal apology for slavery" so the country can move forward and seek "reconciliation, justice, and harmony for all of its citizens." 34 The House, through its Resolution, admitted that a stand-alone apology cannot heal the past and is only the first step towards reconciliation. ${ }^{35}$ The apology itself states:

28 See H. R. Res. 194, 110th Cong. (2008).

${ }^{29}$ Id. at para. 1-4 The relevant "whereas" clauses state:

Whereas millions of Africans and their descendants were enslaved in the United States and

the 13 American colonies from 1619 through 1865;

Whereas slavery in America resembled no other form of involuntary servitude known in

history, as Africans were captured and sold at auction like inanimate objects or animals;

Whereas Africans forced into slavery were brutalized, humiliated, dehumanized, and subjected to the indignity of being stripped of their names and heritage;

Whereas enslaved families were torn apart after having been sold separately from one another.

${ }^{30} \mathrm{Id}$. at para. 6 ("Whereas slavery was not officially abolished until the passage of the 13th Amendment to the United States Constitution in 1865 after the end of the Civil War.").

31 Id. at para. 7-8 ("Whereas after emancipation from 246 years of slavery, African-Americans soon saw the fleeting political, social, and economic gains they made during Reconstruction eviscerated by virulent racism, lynchings, disenfranchisement, Black Codes, and racial segregation laws that imposed a rigid system of officially sanctioned racial segregation in virtually all areas of life. Whereas the system of de jure racial segregation known as "Jim Crow," which arose in certain parts of the Nation following the Civil War to create separate and unequal societies for whites and African-Americans, was a direct result of the racism against persons of African descent engendered by slavery.").

32 Id. at para 12 ("Whereas on July 8, 2003, during a trip to Goree Island, Senegal, a former slave port, President George W. Bush acknowledged slavery's continuing legacy in American life and the need to confront that legacy when he stated that slavery "was ... one of the greatest crimes of history ... The racial bigotry fed by slavery did not end with slavery or with segregation. And many of the issues that still trouble America have roots in the bitter experience of other times. But however long the journey, our destiny is set: liberty and justice for all.").

${ }^{33} I d$.

34 Supra note 28, at para. 17 ("Whereas it is important for this country, which legally recognized slavery through its Constitution and its laws, to make a formal apology for slavery and for its successor, Jim Crow, so that it can move forward and seek reconciliation, justice, and harmony for all of its citizens").

${ }^{35} \mathrm{Id}$. (The Resolution also understands the limit of a stand-alone resolution that:

Whereas a genuine apology is an important and necessary first step in the process of racial reconciliation; Whereas an apology for centuries of brutal dehumanization and injustices cannot erase the past, but confession of the 
Resolved, That the House of Representatives-

(1) acknowledges that slavery is incompatible with the basic founding principles recognized in the Declaration of Independence that all men are created equal;

(2) acknowledges the fundamental injustice, cruelty, brutality, and inhumanity of slavery and Jim Crow;

(3) apologizes to African Americans on behalf of the people of the United States for the wrongs committed against them and their ancestors who suffered under slavery and Jim Crow; and

(4) expresses its commitment to rectify the lingering consequences of the misdeeds committed against African Americans under slavery and Jim Crow and to stop the occurrence of human rights violations in the future. ${ }^{36}$

Many national media outlets viewed the House Resolution as "historic" or "unprecedented," 37 because it was the first-ever, official apology for slavery and segregation. ${ }^{38}$ The House Resolution, however, did not mention reparations, but expressed the House's commitment to rectify the lingering consequences of slavery and Jim Crow. ${ }^{39}$ What the House will do is yet to be seen.

A year later, the Senate issued its own apology on June 18, 2009.40 The apology contained eighteen "whereas" clauses in the preamble, describing the evils of slavery, the legal and systematic enslavement of African-Americans, the legacy of segregation under Jim Crow, and the continual suffering from the "consequences of" the formerly abolished slavery and Jim Crow. ${ }^{41}$ The "whereas" provisions end with an acknowledgment that "it is important" for the people of the United States to "make a formal apology" for slavery and Jim Crow so "they can move forward and seek reconciliation, justice, and harmony for all people of the United States." 42

There are some differences between the "whereas" provisions in the House Resolution and the Senate Resolution. For example, the language in the House Resolution is quite strong in recognizing the discrimination African-Americans still suffer, as shown in the relevant paragraph below:

wrongs committed can speed racial healing and reconciliation and help Americans confront the ghosts of their past.”)

${ }^{36} I d$.

37 See House Issues Formal Apology for Slavery, CBSNEws (June 18, 2009), http://www.cbsnews.com /stories/2008/07/29/national/main4305876.shtml (where national media was uniform in praising the House Resolution on slavery); House Apologizes for Jim Crow and Slavery, AssociaTED PRESS (July 29, 2008), http://www.msnbc.msn.com /id/25921453/ns/politics-capitol_hill/t/house-apologizes-slavery-jim-crow/; see July 29, 2008: U.S. Representative Alcee L. Hastings Reacts to House Apology for Slavery and Segregation, CONGRESSMAN AlCEE HASTINGS (July 29, 2008), http://www.alceehastings.house.gov/index.php?option=com_content\&task=view\&id=197 (where African-American law makers endorsed the Resolution.)

38 U.S. Lawmakers Apologize For Slavery, Jim Crow, NPR (July 30, 2008), http://www.npr.org /templates/story/story.php?storyId=93064166\&ps=rs; Lynne Varner, Editorial, It's Never Too Late to Apologize, SEATTLE TiMES (Aug. 13, 2008), http://seattletimes.nwsource.com/html/opinion/2008109119_lynne13.html (noting that the House's apology is "all part of a longer narrative").

${ }^{39}$ House Apologizes for Jim Crow and Slavery, supra note 37.

40 S. Con. Res. 26, 111th Cong. (2009). The latest major action on the joint resolution was that it had been referred to the House Committee on the Judiciary on June 18, 2009. See Bill Summary \& Status - 111th Congress (20092010) S.Con.Res.26, LiBRARY OF CONG., http://hdl.loc.gov/loc.uscongress/legislation.111sconres26 (last visited Aug. 10 , 2012).

$$
{ }^{41} I d .
$$


Whereas African-Americans continue to suffer from the complex interplay between slavery and Jim Crow-long after both systems were formally abolished-through enormous damage and loss, both tangible and intangible, including the loss of human dignity, the frustration of careers and professional lives, and the long-term loss of income and opportunity; ${ }^{43}$ (emphasis added).

The Senate Resolution's "whereas" clause is similar to the above House Resolution's "whereas" clause, but omits the italic portion:

Whereas African-Americans continue to suffer from the consequences of slavery and Jim Crow laws-long after both systems were formally abolished—-through enormous damage and loss, both tangible and intangible, including the loss of human dignity; 44

Most importantly, the Senate Resolution's Apology section does not "express its commitment to rectify the lingering consequences of the misdeeds committed against African Americans under slavery and Jim Crow." 45 The Senate's Apology, instead, states that it expresses "its recommitment to the principle that all people are created equal and endowed with inalienable rights to life, liberty, and the pursuit of happiness." 46 Also, the Senate does not adopt the House's language "to stop the occurrence of human rights violations in the future." 47 It only "calls on all people of the United States to work toward eliminating racial prejudices, injustices and discrimination from our society." 48

The notoriously glaring difference between the Senate's Apology and the House's Apology is the disclaimer provision that appears at the end of the Senate's Apology. The disclaimer states that "[n]othing in this resolution" "authorizes or supports any claims against the United States" or "serves as a settlement of any claim against the United States." 49 The inclusion of the disclaimer is a political reality to win votes for senators who are afraid that African-Americans would use the apology for reparations claims. ${ }^{50}$

Like the House Resolution, the Senate Resolution is non-binding and merely symbolic. ${ }^{51}$ Some circles have praised the Senate's Apology. ${ }^{52}$ Others have expressed mixed reactions towards the inclusion

43 See H. R. Res. 194, 110th Cong. (2008).

${ }^{44}$ S. Con. Res. 26, 111 th Cong. (1st Sess. 2009).

${ }^{45}$ H. R. Res. 194 para. 4.

${ }^{46}$ S. Res. 26 para. 1.C.

${ }^{47}$ H. R. Res. 194 para. 4.

${ }^{48}$ S. Res. 26 para. 1.C.

${ }^{49} I d$. at para. 2.

${ }^{50}$ Compare David Welna, Senate Apologizes for Slavery, NPR (June 19, 2009), http://www.npr.org/templates/story/ story.php?storyId=105620620 (reporting that "Kansas Republican Sam Brownback, who co-sponsored the measure, says that disclaimer was necessary to win the support of senators who feared the apology could be used by AfricanAmericans seeking reparations."), with Bernie Becker, Senate Approves Slavery Apology, With Reparations Disclaimer, N.Y. TiMES BlOG (June 18, 2009, 4:33 PM), http://thecaucus.blogs.nytimes.com/2009/06/18/senate-approves-slaveryapology-with-reparations-disclaimer/ (reporting that "Senator Roland Burris, Democrat of Illinois and the Senate's only black member, said that the "disclaimer in no way would eliminate future actions that may be brought before this body that may deal with reparations."”).

51 Senate Apologizes for Slavery, Segregation, AssociATEd Press (June 18, 2009), http://www.msnbc.msn.com/id/ 31430118/ns/politics-capitol_hill/t/senate-apologizes-slavery-segregation/ (noting that the Senate has passed similar nonbinding and symbolic resolution in the past, particularly the internment of Japanese-Americans during World War II).

52 Terence Samuel, Senate Apologizes for Slavery, THE ROOT (June 18, 2009), http://www.theroot.com/views/senateapologizes-slavery ("Better way, way, way late than never."). Obama Praises 'Historic' Senate Slavery Apology, AgENCE 
of the disclaimer in the Senate's Apology. ${ }^{53}$ Some critics went further and condemned it for its lack of sincerity ${ }^{54}$ or lack of substance..$^{55}$ Moreover, comparing what Congress has done in addressing the slavery legacy to what some scholars have proposed, the glaring difference is the absence of apology-plus. The apology statements are not accompanied by any programs like monetary payments, a comprehensive study of slavery's legacy, non-repetition methods, or commemorative constructions and activities.

\section{CHINA AND PUBLIC APOLOGIES IN INTELLECTUAL PROPERTY CASES}

\section{A. China's Intellectual Property Law}

Congress may be astounded to discover that China now has strong intellectual property law and enforcement. 56 On the enforcement front, Chinese individuals and companies are rather litigious in enforcing their intellectual property rights. ${ }^{57}$ Recently, the multi-national company, Apple, Inc., encountered a surprisingly painful consequence of the wrath of enforcement exerted by a Chinese trademark owner against Apple for trademark infringement. ${ }^{58}$

China has a complex body of laws protecting and enforcing rights related to names and trademarks. Specifically, there are three different statutes-Trademark Law, Anti-Unfair Competition, and Civil Law_to protect registered trademarks and service marks, trade dress- the overall packaging

FRANCE-PRESSE (June 18, 2009), bttp:/ / www.google.com/ hostednews/afp/article/ALeqM5iyMeHvk7WyJys7iAyehS zik11Yqg.

53 Welna, supra note 50 (reporting on the reaction to the inclusion of the disclaimer in the Senate's Apology from black members of Congress). See also Senate Apology for Slavery Gets Mixed Reaction, NPR (June 24, 2009) http://www.npr.org/templates/story/story.php?storyId=105850676 (documenting the mixed feelings people have about the Senate's apology for slavery); Wenger, supra note 13, at 224 (suggesting that "the Senate and House should make their recent apology for slavery more sincere by setting aside Juneteenth as a national holiday.").

${ }^{54}$ Eugene Kane, Editorial, Senate Apology on Slavery Lacks Sincerity, JOURNAL SENTINEL (June 20, 2009), http:// www.jsonline.com/news/milwaukee/48636877.html (criticizing that unlike the House's action, "the Senate's apology includes a provision that specifically states it can't be used to support any claims for reparations by descendants of American slaves. In other words, this apology basically says: 'I'm sorry, but don't hold me accountable."”).

55 Katrina Browne, Commentary: Slavery Needs More Than an Apology, CNN (Aug. 19, 2009), http://articles.cnn.com/2009-08-19/politics/browne.slavery_1_slave-trade-dewolfs-apology?_s=PM:POLITICS;

Kaimipono David Wenger, Apology Lite: Truths, Doubts, and Reconciliations in the Senate's Guarded Apology for Slavery, 42 Conn. L. REV. Contemplations 1 (2009) (analyzing the Senate's apology for slavery); U.S. Congress Apologizes for Slavery, DAILY VOICE (June 26, 2009), http://www.minorityreporter.net/fullstory.php?id=240 ("The failure to permit reparations is all the more stunning considering the resolution specifically admits that descendants of African American slaves "saw the fleeting political, social, and economic gains they made during Reconstruction eviscerated by virulent racism, lynchings, disenfranchisement, Black Codes, and racial segregation laws that imposed a rigid system of officially sanctioned racial segregation in virtually all areas of life.").

56 Kevin Kwang, China Sees Rising Intellectual Property Tussles, ZDNET (Mar. 13, 2011), http://www.zdnetasia.com/china-sees-rising-intellectual-property-tussles-62304161.htm (reporting that "66,000 IPrelated cases went to litigation in 2011, up 37.7 percent over 2010" in China). In China, the rise in intellectual property litigation is seen as a positive sign for the building of national brands and a strong indication of the fast growth of China's knowledge-based economy. Id.

57 See generally Xuan-Thao Nguyen, The China We Hardly Know: Revealing the New China's Intellectual Property Law Regime, 55 ST. LOUIS L.J. 773, 789-98 (2011) (providing quantitative data on China's intellectual property litigation and comparing it to the United States' declining intellectual property litigation in the same years).

58 See generally Liau Yun Qing, Reports: iPads Taken Off Shelves in China Over Trademark Dispute, ZDNET, (Feb. 14, 2012), http:/ / www.zdnetasia.com/reports-ipads-taken-off-shelves-in-china-over-trademark-dispute-62303847.htm (reporting on the confiscation of iPads from Apple Inc.'s authorized distributors after a lower court held that Apple's use of the name "iPads" infringed upon Proview Technology's IPADS trademark); Ryan Buddenhagen, Apple Still Navigating Chinese iPad Litigation, INT'L Bus. TIMES (Mar. 2, 2012), http://www.ibtimes.co.uk/articles/307791/20120302/seosearch-engine-optimization.htm (reporting that the trademark infringement case has reached the appeals court in Guangdong and that lawyers for both parties are currently engaging in settlement discussions). 
or look and feel of a product or service-and unregistered names. ${ }^{59}$ When an infringer violates the rights protected under the statutes with use of the trademark, trade dress, or name without authorization that is likely to mislead the consumer, the infringer will face civil liability. ${ }^{60}$

The civil liability includes injunction against the defendant. ${ }^{61}$ The defendant must promptly cease the infringing conduct. ${ }^{62}$ In addition, if the plaintiff can demonstrate that she suffered economic harm from the defendant's infringing activities, the plaintiff is entitled to damages. ${ }^{63}$ Alternatively, the plaintiff

59 See generally Xuan-Thao Nguyen, Trademark Reputation Apologetic Justice, 15 U. PENN J. Bus. L. 131 (2012) (analyzing China's three bodies of law).

60 See generally Zhonghua Ren Min Gong He Guo Min Fa Tong Ze (中华人民共和国民法通则) [General Principles of the Civil Law of the People's Republic of China] (promulgated by the Standing Comm. Nat'l People's Cong., Apr. 12, 1986, effective Jan. 1, 1987) http://www.wipo.int/wipolex/en/text.jsp?file_id=182629, translated in http://www.wipo.int/wipolex/en/text.jsp?file_id=182628 [hereinafter China's Civil Law]. The methods of "bearing civil liability" are described in Article 134 of China's Civil Law. Id. at art. 134:

Article 134 The main methods of bearing civil liability shall be:

(1) cessation of infringements;

(2) removal of obstacles;

(3) elimination of dangers;

(4) return of property;

(5) restoration of original condition;

(6) repair, reworking or replacement;

(7) compensation for losses;

(8) payment of breach of contract damages;

(9) elimination of ill effects and rehabilitation of reputation; and

(10) extension of apology.

The above methods of bearing civil liability may be applied exclusively or concurrently. When hearing civil cases, a people's court, in addition to applying the above stipulations, may serve admonitions, order the offender to sign a pledge of repentance, and confiscate the property used in carrying out illegal activities and the illegal income obtained therefrom.

${ }^{61}$ China Supreme People's Court has dictated that " $[\mathrm{w}]$ hen hearing cases of infringement upon the exclusive right to use registered trademarks, the people's court may, pursuant to Article 134 of the General Principles of Civil Law, Article 53 of the Trademark Law and the specific circumstances of the cases, rule to order the infringer to bear such civil liabilities as to cease and desist the infringement, eliminate interference, compensate for losses and eliminate adverse effects. It may also order such civil sanctions as fines, confiscation of the infringing goods, counterfeit trademark representations and materials, tools and equipment used specifically to produce infringing goods. The amount of fines may be determined by reference to the Implementing Rules of the Trademark Law of the People's Republic of China." [Interpretation by the Supreme People's Court Relating to Application of Law in Adjudication of Cases of Trademark Civil Disputes] (promulgated by the Adjudication Comm. of the Sup. People's Ct., Oct. 12, 2002, effective Oct. 12, 2002) http:/ / www.lindaliugroup.com/web/01/en_laws_read.asp?id=1365 htm [hereinafter Trademark Law Interpretation].

${ }^{62} I d$.

${ }^{63}$ Zhonghua Ren Min Gong He Guo Shang Biao Fa (中华人民共和国商标法) [Trademark Law of the People’s Republic of China] (promulgated by the Standing Comm. Nat'l People's Cong., Aug 23, 1982, effective Mar. 1, 1983) http://www.wipo.int/wipolex/en/text.jsp?file_id=181402, translated in http://www.wipo.int/wipolex/en/text.jsp?file_id=131395 [hereinafter China's Trademark Law]. Id. at art. 56 provides in relevant part:

The amount of compensation for the damage caused by the infringement of the exclusive right to use a trademark shall be assessed on the basis of the profits which the infringer has earned through the infringement, or the losses which the infringee has suffered, which shall include the reasonable expenses for stopping such infringement paid by the infringee.

China Supreme People's Court instructs how damages must be calculated in trademark-related cases, as provided in Trademark Law Interpretation, supra note 61, at art. 14: 
can select damages in the form of the defendant's profits gained from unauthorized use of the trademark, trade dress or name. ${ }^{64}$ If the court cannot quantify the damages, the law provides statutory damages. ${ }^{65}$

Most importantly, if the defendant's infringement maliciously or intentionally misleads the public as to the source of goods or services, Chinese courts have the power under the statutes to order the defendant to make a public apology. ${ }^{66}$ Courts will instruct the defendant to use the public apology to eliminate any ill effects stemming from the defendant's conduct. ${ }^{67}$ In some cases, courts will approve the content of the apology before the defendant publishes it in a newspaper or trade journal. Courts often dictate in what journal or newspaper the defendant will publish the apology.68 In the event that the defendant fails to publish the apology, courts will direct the plaintiff to prepare and publish the public apology in the defendant's name. ${ }^{69}$ The defendant must then pay the plaintiff for the cost associated with the making and publishing of the apology. ${ }^{70}$

Likewise, with respect to copyrights, there is a body of laws comprising Copyright Law and Civil Law related to copyrighted works and enforcement against copyright infringements. Under the Copyright Law, ${ }^{71}$ works of authorship qualified for copyright protection include written, oral, musical,

The losses caused by the infringement as provided for in Paragraph 1 of Article 56 of the Trademark Law may be calculated by multiplying the amount of sale reduction of the goods suffered by the claimant as a result of the infringement or the amount of sale of the infringing goods by the unit profit of the goods bearing the registered trademark.

The amount of gains obtained as a result of infringement as provided for in Paragraph 1 of Article 56 of the Trademark Law may be calculated by multiplying the quantity of sales of the infringing goods by the unit profit of such goods sold; if the unit profit of such goods cannot be ascertained, the calculation shall be based on the unit profit of the goods bearing the registered trademark.

${ }^{64}$ China Supreme People's Court instructs that the plaintiff has the right to select how damages should be calculated, as provided in Trademark Law Interpretation, supra note 61, at art. 13 ("When the people's court ascertains the amount of compensation to be paid by the infringing party pursuant to Paragraph 1 of Article 56 of the Trademark Law, it may calculate the amount of compensation on the basis of the calculating formula selected by the claimant.").

${ }^{65}$ China's Trademark Law, supra note 63, at art. 56 ("If it is difficult to determine the profits which the infringer has earned through infringement or the losses which the infringee has suffered as referred in the preceding paragraph, the people's court shall make a sentence of compensation under the amount of 500,000 Yuan RMB in accordance with the seriousness of infringing acts.").

${ }^{66}$ China's Civil Law, supra note 60, at art. 118 (if the exclusive right to use a trademark is infringed, the trademark registrant has the right to demand that "the infringement be stopped, its ill effects be eliminated and the damages be compensated”). See China's Civil Law, supra note 60, at art. 118. Likewise, when a legal person's "right of name, reputation or honor" is infringed, the person has the right to "demand that the infringement be stopped," the individual's or business entity's "reputation be rehabilitated," and the "ill effects be eliminated" under Article 120 of China's Civil Law. See China's Civil Law, supra note 60, at art. 120. See also China's Civil Law, supra note 60, at art. 134 (listing "elimination of ill effects and rehabilitation of reputation" and "apology" among the methods of civil liability).

67 See Fangfang Ceramics Manufactory v. Hengsheng Ceramics and Bldg. Materials Manufactory (Higher People's Ct. of Fujian Province Dec. 30, 1998) (China) (ordering an injunction against the defendant under art. 118 of China's Civil and instructing the defendant to pay for damages and publish an apology in a newspaper).

68 See generally Tianjin (Higher People's Ct. of Heilongjian Province Dec. 28, 1994) (China) (mandating that the defendant must submit the content of the public apology to the court for approval prior to publication).

${ }^{69}$ China Pharm. Univ. v. Furui Tech. Co., Ltd. (Higher People’s Ct. of Jiangsu Province Jan. 31, 2005) (China) (admonishing the defendants of the consequences if they fail to timely publish their public apology).

70 See id. See also Xuan-Thao Nguyen, Apologies as Intellectual Property Remedies: Lessons from China, 44 CONN. L. REV. 883, 916 (2012).

${ }^{71}$ Zhonghua Ren Min Gong He Guo Zhuzuo Quan Fa (中华人民共和国著作权法) [Copyright Law of the People’s Republic of China] (promulgated by the Standing Comm. Nat'l People's Cong., Sept. 7, 1990, effective June 1, 1991, 
choreographic, art, architecture, photographic, cinematographic, graphic, computer software, and other works as provided for in the laws and regulations. ${ }^{72}$ The term "copyright" under Chinese law differs from the U.S. definition. ${ }^{73}$ The Chinese "copyright" term covers both property rights and personality rights, the latter being similar to moral rights under U.S. law. ${ }^{74}$

Chinese copyright's personality right provides authors and owners of a copyright with the right of publication, ${ }^{75}$ authorship, ${ }^{76}$ alteration, ${ }^{77}$ and integrity. ${ }^{78}$ Under Chinese copyright's property right, authors and owners of copyrights enjoy the right of reproduction, ${ }^{79}$ distribution, ${ }^{80}$ rental, ${ }^{81}$ exhibition, ${ }^{82}$ performance, ${ }^{83}$ showing, 84 broadcast, 85 communication of information on networks, ${ }^{86}$ producing

amended Feb. 26, 2010, effective Apr. 1, 2010) http://www.wipo.int/wipolex/en/text.jsp?file_id=182065, translated in http://www.wipo.int/wipolex/en/text.jsp?file_id=186569 [hereinafter China's Copyright Law].

${ }^{72} I d$. at art. 3.

${ }^{73}$ Under U.S. copyright law, the term "copyright" means a bundle of exclusive rights granted to the authors. The exclusive rights are listed in 17 U.S.C. $\$ 106$ (2012):

(1) to reproduce the copyrighted work in copies or phonorecords;

(2) to prepare derivative works based upon the copyrighted work;

(3) to distribute copies or phonorecords of the copyrighted work to the public by sale or other transfer of ownership, or by rental, lease, or lending;

(4) in the case of literary, musical, dramatic, and choreographic works, pantomimes, and motion pictures and other audiovisual works, to perform the copyrighted work publicly;

(5) in the case of literary, musical, dramatic, and choreographic works, pantomimes, and pictorial, graphic, or sculptural works, including the individual images of a motion picture or other audiovisual work, to display the copyrighted work publicly; and

(6) in the case of sound recordings, to perform the copyrighted work publicly by means of a digital audio transmission.

${ }^{74}$ China's Copyright Law, supra note 71, at art. 10; Zhiwen Liang, Between Freedom of Commerce and Protection of Moral Rights: The Chinese Experience and a Comparative Analysis, 57 J. COPYRIGHT SOC'Y U.S.A. 107, 114-15 (2010) (tracing the history of moral right in Chinese copyright law). U.S. copyright law, on the other hand, does not protect moral rights or the "personality" of the author. Instead, U.S. copyright law provides protection to works of visual art such as paintings, drawings, prints, and sculptures. The author of such work has the right to claim authorship, to prevent the use of the author's name on works that the author did not create, and to prevent the use of the author's name on works that have been modified or distorted. For visual art works made after 1991, the right will subsist for the life of the author. See 17 U.S.C. $\int 106 \mathrm{~A}(2002)$.

75 China's Copyright Law, supra note 71, at art. 10 (l) (right of publication is the right to decide whether to make a work available to the public).

${ }^{76} \mathrm{Id}$. at art. 10(2) (right of authorship is the right to claim authorship and to have the author's name mentioned in connection with the work).

${ }^{77} \mathrm{Id}$. at art. 10(3) (right of alteration is the right to alter or authorize others to alter one's work).

${ }^{78} \mathrm{Id}$. at art. 10(4) the right of integrity, that is, the right to protect one's work against distortion and mutilation.

${ }^{79} \mathrm{Id}$. at art. 10(5) the right of reproduction, that is, the right to produce one or more copies of a work by printing, photocopying, lithographing, making a sound recording or video recording, duplicating a recording, or duplicating a photographic work or by any other means.

${ }^{80} \mathrm{Id}$. at art. 10(6) the right of distribution, that is, the right to make available to the public the original or reproductions of a work though sale or other transfer of ownership.

81 China's Copyright Law, supra note 71, at art. 10(7) the right of rental, that is, the right to authorize, with payment, others to temporarily use cinematographic works, works created by virtue of an analogous method of film production, and computer software, except any computer software that is not the main subject matter of rental.

${ }^{82} \mathrm{Id}$. at art. 10(8) the right of exhibition, that is, the right to publicly display the original or reproduction of a work of fine art and photography.

${ }^{83} \mathrm{Id}$. at art. 10(9) the right of performance, that is, the right to publicly perform a work and publicly broadcast the performance of a work by various means.

${ }^{84} \mathrm{Id}$. at art. 10(10) the right of showing, that is, the right to show to the public a work, of fine art, photography, cinematography and any work created by analogous methods of film production through film projectors, over-head 
cinematographic work, ${ }^{87}$ adaptation, ${ }^{88}$ translation, ${ }^{89}$ compilation $^{90}$ and any other rights a copyright owner is entitled to enjoy. ${ }^{91}$ In addition, the copyright owner may assign or license others to use the enumerated property rights and receive remuneration for the exchange. ${ }^{92}$

China's Copyright Law also contains provisions relating to works made for hire. ${ }^{93}$ The duration of copyright protection for an individual author is the life of the author plus fifty years. ${ }^{94}$ For a work made

projectors or any other technical devices.

${ }^{85} \mathrm{Id}$. at art. 10(11) the right of broadcast, that is, the right to publicly broadcast or communicate to the public a work by wireless means, to communicate to the public a broadcast work by wire or relay means, and to communicate to the public a broadcast work by a loudspeaker or by any other analogous tool used to transmit symbols, sounds or pictures.

${ }^{86} \mathrm{Id}$. at art. 10(12) the right of communication of information on networks, that is, the right to communicate to the public a work, by wire or wireless means in such a way that members of the public may access these works from a place and at a time individually chosen by them.

87 China's Copyright Law, supra note 71, at art. 10(13) the right of making cinematographic work, that is, the right to fixate a work on a carrier by way of film production or by virtue of an analogous method of film production.

${ }^{88} \mathrm{Id}$. at art. 10(14) the right of adaptation, that is, the right to change a work to create a new work of originality.

${ }^{89} \mathrm{Id}$. at art. 10(15) the right of translation, that is, the right to translate a work in one language into one in another language.

${ }^{90} \mathrm{Id}$. at art. 10(16) the right of compilation, that is, the right to compile works or parts of works into a new work by reason of the selection or arrangement.

${ }^{91} \mathrm{Id}$. at art. 10(17).

$92 \mathrm{Id}$. at art. 10 ("A copyright owner may authorize another person to exercise the rights under the preceding paragraphs (5) to (17), and receive remuneration pursuant to an agreement or this Law. A copyright owner may assign, in part or in whole, the rights under the preceding paragraphs (5) to (17), and receive remuneration pursuant to an agreement or this Law.").

93 China's Copyright Law, supra note 71, at art. 16:

A work created by a citizen in the fulfillment of tasks assigned to him by a legal entity or other organization shall be deemed to be a work created in the course of employment. The copyright in such work shall be enjoyed by the author, subject to the provisions of the second paragraph of this Article, provided that the legal entity or other organization shall have a priority right to exploit the work within the scope of its professional activities. During the two years after the completion of the work, the author shall not, without the consent of the legal entity or other organization, authorize a third party to exploit the work in the same way as the legal entity or other organization does.

In any of the following cases the author of a work created in the course of employment shall enjoy the right of authorship, while the legal entity or other organization shall enjoy the other rights included in the copyright and may reward the author:

(1) drawings of engineering designs and product designs and maps, computer software and other works created in the course of employment mainly with the material and technical resource of the legal entity or other organization and under its responsibility;

(2) works created in the course of employment where the copyright is, in accordance with laws, administrative regulations or contracts, enjoyed by the legal entity or other organization.

94 Id. at art. 21. The term of protection for the right of publication and the rights referred to in Article 10, paragraphs (5) to (17), of this Law in respect of a work of a citizen shall be the lifetime of the author and fifty years after his death, and expires on 31 December of the fiftieth year after the death of the author. In the case of a work of joint authorship, such term shall expire on 31 December of the fiftieth year after the death of the last surviving author.

The term of protection for the right of publication and the rights provided for in Article 10, paragraphs (5) to (17), of this Law in respect of a work where the copyright belongs to a legal entity or other organization or in respect of a work created in the course of employment where the legal entity or other organization enjoys the copyright (except the 
for hire, the duration is fifty years. 95 The "personality" or moral rights, such as rights of authorship, alteration and the integrity of an individual author are "unlimited in time." 96

With respect to civil liability, if an infringer violates any of the acts protected under Chinese Copyright Law, ${ }^{97}$ the infringer will face injunctions and damages. ${ }^{98}$ In addition, depending on the circumstances, the infringer might be required to make a public apology. ${ }^{99}$

China's General Principles of the Civil Law of the People's Republic of China ("Civil Law") provides several provisions addressing the protection of copyrights and civil liability in copyright infringement. ${ }^{100}$ Specifically, Article 94 provides that authors and copyright owners "shall be entitled to

right of authorship), shall be fifty years, and expires on 31 December of the fiftieth year after the first Publication of such work, provided that any such work that has not been published within fifty years after the completion of its creation shall no longer be protected under this Law.

The term of protection for the right of publication or protection for the right of publication or the rights referred to in Article 10, paragraphs (5) to (17), of this Law in respect of a cinematographic work, a work created by virtue of an analogous method of film production or a photographic work shall be fifty years, and expires on 31 December of the fiftieth year after the first publication of such work, provided that any such work that has not been published within fifty years after the completion of its creation shall no longer be protected under this Law.

${ }^{95} I d$. at art. 21.

${ }^{96}$ Compare id. at art. 20 with 17 U.S.C. \$106A (U.S. copyright law for the limited "moral" rights afforded authors of works of visual art against unauthorized use of the author's name on works not created by the author or modifications and distortions of visual art works only during the life of the author).

${ }^{77}$ Cbina's Copyright Law, supra note 71, at art. 46 lists acts of infringement.

Anyone who commits any of the following acts of infringement:

(1) publishing a work without the permission of the copyright owner;

(2) publishing a work of joint authorship as a work created solely by oneself, without the permission of the other co-authors;

(3) having one's name mentioned in connection with a work created by another, in order to seek personal fame and gain, where one has not taken part in the creation of the work;

(4) distorting or mutilating a work created by another;

(5) plagiarizing a work of another person;

(6) exploiting by exhibition, film production or any analogous method of film production, or by adaptation, translation, annotation, or by other means, without the permission of the copyright owner, unless otherwise provided in this Law;

(7) exploiting a work created by another person without paying remuneration as prescribed by regulations;

(8) rending a work, sound recording or video recording, without the permission of the copyright owner of a cinematographic work, a work created by virtue of an analogous method of film production, computer software, sound recording or video recording or the owner of a copyright-related right unless otherwise provided in this Law;

(9) exploiting the typographic arrangement of a book or periodical without the permission of the publisher;

(10) broadcasting live a performance or communicating the live performance to the public, or recording his performance without the permission of the performer; or

(11) committing any other act of infringement of copyright and of other rights and interests relating to copyright.

${ }^{98} I d$. at art. 46 states that the infringer "shall bear civil liability for such remedies as ceasing the infringing act, eliminating the effects of the act, making an apology or paying compensation for damages, depending on the circumstances." See also id. at art. 47. Statutory damages will not exceed "500,00" yuan depending on the circumstances of the infringing act. Id. at art. 48.

${ }^{99}$ See id. at arts. 46 and 47.

100 China's Civil Law is a comprehensive body of law which was formulated "in accordance with the 
sign their names as authors, issue and publish their works and obtain remuneration.”101 Articles $118^{102}$ and 134 provide remedies in infringement cases where copyrights are violated. The remedies, under Article 134, include injunctions, damages, elimination of "the ill effects," as well as an "apology" from the wrongdoer. 103

In addition, China's Anti-unfair Competition Law is broad enough in scope to prevent conduct deemed to be unfair competition. For example, Article 2 of China's Anti-Unfair Competition Statue dictates that business individuals and companies "abide by the principle of voluntariness, equality, impartiality, honesty and good faith, and also adhere to public commercial morals in their business transactions." 104 The definition of "unfair competition" means business activities that "damage" others" "legal rights and interests, disturb the order of social economy and violation provisions" of the AntiUnfair Competition statute. ${ }^{105}$ In addition, in Article 5 of the Anti-Unfair Competition Law, the law prohibits the use of "name, package, decoration" of a well-known commodity to "confuse consumers." 106 Article 5 also prohibits the use of registered trademarks belonging to others. ${ }^{107}$ Violators of the Anti-Unfair Competition Law bear liabilities listed in Articles 20-29 of China's Anti-Unfair Competition Law ${ }^{108}$ and Article 134 of China's Civil Law Statute. ${ }^{109}$ Injunction, damages and apology to eliminate ill effects are among the remedies the violators must owe to the injured party.

In summary, Chinese laws on trademarks and copyrights are a strong protection system against statutory wrongs committed by infringers. In trademark cases, where the infringer intentionally or maliciously misleads the public as to the trademark's source or affiliation and harms both the plaintiff and the public, a public apology is ordered. In copyright cases, when injury occurs to the "personality rights," courts order a public apology. In these types of cases, public apology 110 is supplemental to injunction and damages. ${ }^{111}$

Constitution and the actual situation in our country, drawing upon our practical experience in civil activities for the purpose of protecting the lawful civil rights and interests of citizens and legal persons and correctly adjusting civil relations, so as to meet the needs of the developing socialist modernization" and the Civil Law is the foundation to "adjust property relationships and personal relationships between ... citizens, ... legal persons, ... citizens and legal persons" China's Civil Law, supra note 60, at arts. 1-2.

${ }^{101} \mathrm{Id}$. at art. 94.

${ }^{102} I$ d. at art. 118 ("If the rights of authorship (copyrights) ... of citizens or legal persons are infringed upon by such means as plagiarism, alteration or imitation, they shall have the right to demand that the infringement be stopped, its ill effects be eliminated and the damages be compensated for.")

${ }^{103}$ Id. at art. 134.

104 Zhonghua Ren Min Gong He Guo Fan Bu Zhengdang Jingzheng Fa (中华人民共和国反不正当竞争法) [Law of the People's Republic of China Against Unfair Competition] (promulgated by the Standing Comm. Nat'l People's Cong., Sept. 2, 1993, effective Dec. 1, 1993) http://www.wipo.int/wipolex/en/text.jsp?file_id=181337, translated in http://www.wipo.int/wipolex/en/text.jsp?file_id=125970 [hereinafter China's Anti-Unfair Competition Law]. Id. at art. 2.

$105 \mathrm{Id}$.

${ }^{106}$ China's Civil Law, supra note 60, at art. 5. See generally Zuigao Ren Min Fayuan Guanyu Shenli Bu Zhengdang Jingzheng Min Shi Anjian Yingyong Falu Ruogan Wenti de Jieshi (最高人民法院关于审理不正当竞争民事案件应用法律若干问题的解释) [Interpretation of the Supreme People's Court on Some Matters About the Application of Law in the Trial of Civil Cases Involving Unfair Competition] (promulgated by the Sup. People's Ct., Dec. 30, 2006, effective Feb. 1, 2007) http://www.wipo.int/wipolex/en/text.jsp?file_id=182408 (China), translated in http://www.wipo.int/clea/docs_new/pdf/en/cn/cn104en.pdf (providing interpretations of art. 5 of China's Anti-Unfair Competition Law).

107 China's Anti-Unfair Competition Law, supra note 104, at art. 5.

$108 I d$. at arts. 20-29.

${ }^{109}$ China's Civil Law, supra note 60, at art. 20, 134.

110 See Peter K. Yu, From Pirates to Partners (Episode II): Protecting Intellectual Property in Post-WTO China, 55 AM. U. L. REV. 901, 952 (2006) (noting that arts. 37 and 46 of China's Copyright Law provide the remedy of public apology).

111 See Anne M. Wall, Intellectual Property in China: Enforcing Trademark Rights, 17 MARQ. SPORTS L. REV. 341,362 


\section{B. The Chinese Court's Decisions in Intellectual Property Cases}

The prevalent view outside China is that there is a lack of recourse through the Chinese judicial system with respect to intellectual property infringement in China. A review of written and published decisions from the Chinese People's Courts challenges this uninformed view. The decisions below illustrate the context of intellectual property infringement conduct and demonstrate how courts apply the laws to restore justice. Specifically, courts instruct the defendants to apologize to the plaintiffs for intentional or willful intellectual property infringement. The apology is in addition to damages and injunctive relief. 1. Zhang Linying and Other Three Persons v. Guangyuan Co. Ltd., Chinese
Revolutionary Museum and Gongmei Corp. Group

The plaintiffs are heirs of the artist Dong Xiwen who in 1953 painted the oil painting, "The Founding Ceremony of New China" (hereinafter "the Painting").112 Through inheritance law, the plaintiffs are the owners to the copyright for the Painting. The plaintiffs brought a copyright infringement action against the Chinese Revolutionary Museum and its business partners, alleging that the defendants made copies of the Painting without the plaintiffs' authorization. Specifically, in 1999, the Museum and its business partner, Guangyuan, entered into an agreement to reproduce 11,000 copies of the Painting in three different sizes. Shortly thereafter, the Museum and Guangyuan agreed to make even more copies of the Painting: "500 copies of the masterwork edition, 1,000 copies of the collection edition and 1,000 copies of the commemorative edition."113 Guangyuan distributed the copies of the Painting with a statement indicating that the "Chinese Revolutionary Museum transfers the copyright of the oil painting 'The Founding Ceremony of China' to Shanghai Guangyuan Artworks Co. Ltd, to manufacture gold foil paintings."114

The Intermediate People's Court of Beijing found that in 1953 the artist Dong Xiwen completed the Painting and affixed his signature onto the canvas. ${ }^{115}$ The Painting was subsequently preserved in the Chinese Revolutionary Museum. The Court noted that the artist died in 1973, leaving behind his wife and three children. The Court applied the 1990 version of China's Copyright Law, and held that the plaintiffs, Dong Xiwen's wife and children, are the rightful heirs to the copyright for the Painting. ${ }^{116}$ Therefore the plaintiffs are the copyright owners of the Painting and have "the right to use and the right to remuneration" with respect to the Painting under Copyright Law. ${ }^{117}$

The Court found that the Museum had only the right to exhibit the Painting even though the Museum had possession of the original copy of the Painting. ${ }^{118}$ Under Chinese Copyright Law, ownership of the original copy of the Painting did not vest the Museum with the copyright in the Painting. Without copyright ownership, the Museum had no right to make copies or authorize others to make copies and distribute them. The Court noted that although the Museum was fully aware of copyright ownership belonging to the artist's heirs, the Museum unlawfully provided the film of the Painting to Guangyuan to make mass copies for distribution.119 Consequently, the Museum and

(2006) (recognizing that modern Chinese Copyright Law includes apologies as remedies).

112 Zhang Linying v. Guangyuan Co. (Higher People’s Ct. of Beijing Dec. 16, 2002).

${ }^{113} I d$.

${ }^{114} I d$.

${ }^{115} I d$. (the lower court, the Interm. People's Ct. of Beijing, rendered its decision on June 19, 2002).

$116 I d$.

117 Id.

118 Linying, supra note 112.

${ }^{119} \mathrm{Id}$. 
Guangyuan violated the plaintiffs' copyright to the Painting and therefore were subject to liability. The Court ordered the defendants to stop their infringing activities and forbade them from using the Painting in any form without the plaintiffs' permission. ${ }^{120}$ The defendants were ordered to pay the plaintiffs 260,000 yuan for economic losses suffered by the plaintiffs. In addition, the Court instructed the defendants to publish an apology to the plaintiffs in the Legal Daily. ${ }^{121}$ The content of the apology was subject to the Court's approval. The Court stated that, if the defendants failed to publish the apology, the Court would publicize the judgment in the Legal Daily and charge the defendants for the associated cost. 122

The defendants appealed the decision to the Higher People's Court of Beijing. The Higher Court rejected the defendants' argument that the artist Dong Xiwen had completed the Painting as part of his job-related work donated to the government. ${ }^{23}$ The defendants did not submit evidence to support their copyright ownership argument. The Higher Court affirmed the Intermediate Court's judgment.124

\section{Golden Human Computer Co. Ltd v. HST Scientific and Technological Development Center}

The plaintiff Golden Human Computer Co. brought a trademark infringement and unfair competition action against the defendant HST for the unauthorized use of the plaintiff's trademark "Gushen" on software products. ${ }^{125}$ The plaintiff filed its complaint with the Haidian District People's Court in Beijing. ${ }^{126}$

In late 1997, the plaintiff developed a special software for use in the stock market. The plaintiff marketed the software under the name "Gushen" in numerous newspapers, including Computer Workers' Daily, China Youth Daily and other media. By the end of 1999, the Gushen software was ranked first among software products sold in software stores in Beijing. The plaintiff registered the copyright for the Gushen software with the State Copyright Bureau and also obtained a trademark registration for the Gushen trademark for "computer hardware" classification in April 1999. In addition, in December 1999, the plaintiff received a Software Product Certificate for its Gushen software products in the Beijing Municipality, issued by a government software agency. Subsequently, in April 2000, the plaintiff applied to expand the scope of its "Gushen" trademark registration to cover the "computer software" classification. ${ }^{127}$

The defendant, HST, a software development company, began to market and sell its software products under the name "Gushen2000" in early 2000. ${ }^{128}$ Gushen2000 software was for use in the stock market. The defendant marketed the Gushen2000 software in various newspapers and on the Internet. ${ }^{129}$

The Haidian Court found that under China's Trademark Law, trademark infringement is
${ }^{120} \mathrm{Id}$.
$121 \mathrm{Id}$.
$122 \mathrm{Id}$.
${ }^{123} \mathrm{Id}$.
${ }^{124}$ Linying, supra note 112.
125 Golden Human Computer Co. v. HST Scientific and Technological Dev. Ctr. (Beijing First Interm. People's Ct. Sept. 27, 2000).

${ }_{126} \mathrm{Id}$.

${ }^{127} \mathrm{Id}$.

$128 \mathrm{Id}$.

${ }^{129} \mathrm{Id}$. 
committed when unauthorized use of a trademark occurs on either identical or similar goods. ${ }^{130}$ Therefore, the plaintiff's exclusive right to use the Gushen trademark was not limited to computer hardware; the right was extended to similar goods as well. The plaintiff was the only entity with the exclusive right to use the Gushen trademark on computer hardware and software. Although the plaintiff originally registered the trademark Gushen only for computer hardware, the Haidian Court explained that computer hardware and software are "closely related to computer operation and they belong to a big category in the commodity classification table." 131 Consequently, use of the same trademark on both computer hardware and software would lead the consumer to believe that the products came from the same source. Accordingly, in the stock market "consumers would be easy to mistake" the defendant's Gushen2000 software products with the plaintiffs Gushen software products. ${ }^{132}$ Without the plaintiff's permission, the defendant's use of the Gushen trademark infringed the plaintiff's exclusive right. 133

The Haidian Court also applied China's Unfair Competition Law which provided that unfair competition occurs when a person or entity is "using for a commodity without authorization a unique name, package or decoration similar to that of another's famous commodity, thereby confusing the commodity with that famous commodity and leading the purchasers to mistake the former for the latter."134 Here, the plaintiff's Gushen trademark was not a general name for software. The plaintiff had extensively advertised the Gushen name to build and increase goodwill and recognition for the name. The Gushen software achieved "certain prestige" in the software stock market, and therefore enjoyed being "a kind of famous commodity." 135 The plaintiff, therefore, had the exclusive right to the name Gushen, and thereafter the right to add a new year to the name for new versions of the software. The defendant, without permission, used the name Gushen and added the new year for a new generation of software when it sold Gushen2000 in the year 2000. Such use, the Haidian Court concluded, violated China's Unfair Competition Law and the defendant must bear civil liability. ${ }^{136}$

On June 28, 2000, the Haidian Court ordered the defendant to stop using the name Gushen in any form on packages of its software products. ${ }^{137}$ The Haidian Court also directed the defendant to pay compensatory damages to the plaintiff. In addition, the defendant was ordered to publish a public apology to the plaintiff in a computer trade publication and on the defendant's homepage at its website. ${ }^{138}$ The defendant appealed the Haidian Court's decision to the Intermediate People's Court. ${ }^{139}$ At the appellate level, the parties reached a settlement. Specifically, after a reconciliation presided over by the Intermediate People's Court, the defendant agreed to stop using the name "Gushen" on its software packages. The defendant agreed to pay for damages and make an apology to the plaintiff. As of September 27, 2000, the defendant had already complied with the Haidian Court's judgment by making a public apology to the plaintiff. ${ }^{140}$

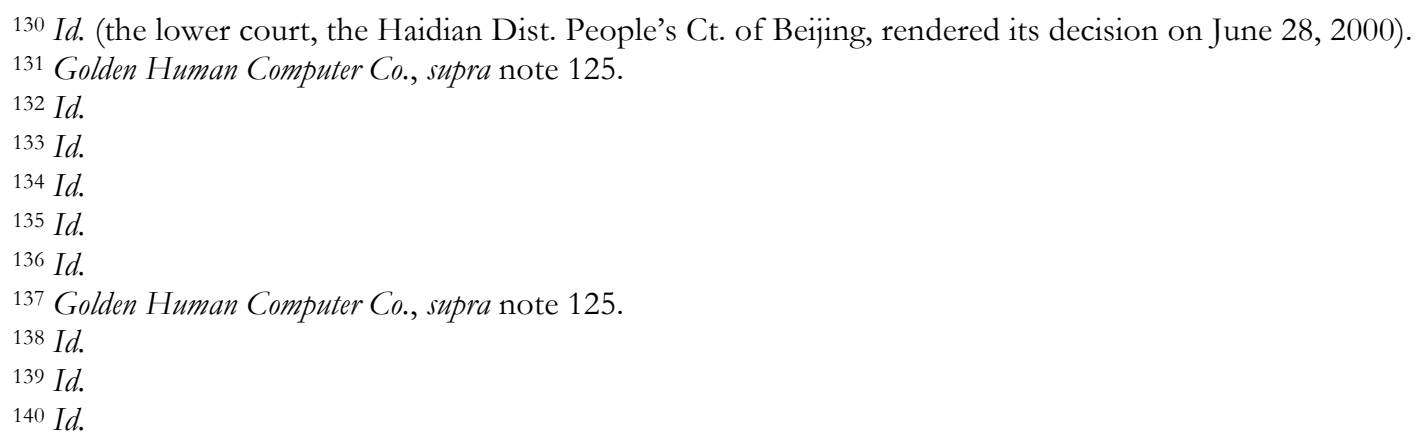




\section{Starbucks Corporation and Shanghai President Coffee Corporation $v$. Shanghai Starbucks Café Company Limited and Shanghai Starbucks Café Company Limited, Nanjing Road Branch}

Starbucks Corporation is a well-known company for its coffee retail business in the United States and worldwide. ${ }^{141}$ In January 1999, Starbucks opened its first chain store in Beijing. Starbucks advertised its trademark, products and services in various sources in China. By December 2003, Starbucks had 49 stores through its franchising program in major cities in China.

On March 2, 2000, Starbucks established a Chinese-foreign co-operative enterprise for coffee, teahouse, refreshments, ice creams, and catering in China after it received an approval from the Chinese Administrative Authority for Industry and Commerce. Starbucks is the owner of many "Starbucks" trademarks for coffee products and services. Starbucks entered into a trademark license agreement with its Chinese affiliate to use the various Starbucks trademarks in connection with the development and operation of Starbucks stores in China. Starbucks and its Chinese affiliate ("plaintiffs") brought a trademark infringement and unfair competition suit against Shanghai Starbucks Café Company Limited and Shanghai Starbucks Café Company Limited, Nanjing Road Branch (“defendants”).

The defendants operated a business enterprise for drinks and Western-style food in Shanghai under the trade name "Starbucks" (in Chinese). Specifically, the defendants received pre-approval for its retail enterprise name on October 20,1999, and then established its store on March 9, 2000. Three years later, on July 1, 2003, the defendants established a branch store on Nanjing Road. The defendants used the name "Starbucks" on boxes, coffee menus, seat separation boards, invoices, payment slips, and name cards in their coffee business at both the Xianxia store and Nanjing Road branch.

The Shanghai Intermediate Court held that the plaintiffs' "Starbucks" trademark is a well-known trademark under Chinese Trademark Law upon evaluating the following factors: (1) how well the trademark is known by the relevant public; (2) the duration of use of the trademark; (3) the extent and geographic scope of advertisements using the trademark; (4) the record of protection of the trademark as a well-known trademark; and (5) other various factors for which the trademark is well-known. ${ }^{142}$ The evidence supported the fact that the Starbucks trademark is well-known under Chinese Trademark Law.

The Shanghai Intermediate Court then proceeded on the issue of trademark infringement and unfair competition committed by the defendants. The court noted that the plaintiffs obtained their trademark registration for the Starbucks trademark on December 28, 1999. That meant the plaintiffs acquired the exclusive right to use the trademark on that date. The defendants, on the other hand, received pre-approval for their enterprise name on October 20, 1999, and established their store on March 9, 2000. Applying the relevant provisions of the Chinese "Implementation Measures for the Registration Administration of Enterprise Names," the court stated that an enterprise may enjoy the right of name as of the date of establishment. Therefore, the plaintiffs acquired "the right to the trademark 'Starbucks'... earlier than the defendants' right to their enterprise names."'143

Moreover, on the defendants' "subjective malice of taking advantage of" the plaintiffs' wellknown trademark by registering the trademark as their own enterprise name, the court noted that due to the wide international prestige and good reputation of Starbucks' trademarks, the Starbucks name

${ }^{141}$ Starbucks Corp. v. Shanghai Starbucks Café Co. (Shanghai Higher People’s Ct. Dec. 20, 2006).

${ }^{142} I d$. (the lower court, the Shanghai Interm. People's Ct., rendered its decision on Dec. 31, 2005).

${ }^{143} I d$. 
became "prestigious in the Mainland of China rapidly."144 The court found that the defendants took advantage of the plaintiffs' prestigious trademark, as seen in Mr. Mao's - General Manager of the defendants' Shanghai Starbucks stores - interview conducted by the Jiefang Daily newspaper. Mr. Mao touted to the reporter that "US Starbucks Corporation established more than 4,000 stores, and he liked the brand 'Starbucks,' so he rush-registered 'Starbucks."'145 Even though the defendants later recanted what they said in the interview and substituted a new story for why they selected the name "Starbucks," the court found their new story to be "very far-fetched."146 The court concluded that the defendants" registration of Starbucks as their enterprise name "had the obvious malice of taking advantage of" the plaintiffs' trademark, "had caused the public to misidentify or misunderstand" the trademark registrant and the enterprise name owner, and "constituted unfair competition." 147 Applying both the Trademark Law and Anti-Unfair Competition Law, the court ordered the defendants to cease the infringement and unfair competition activities of using the plaintiffs' trademark and make a payment of 500,000 yuan to the plaintiffs for their economic losses. ${ }^{148}$ With respect to eliminating negative influences and making an apology, the court ordered the defendants to "publish an announcement on Xinmin Evening News (the contents shall be subject to the court's verification) to make an apology" to the plaintiffs. ${ }^{149}$

The defendants subsequently appealed to Shanghai Higher People's Court. The Higher Court rejected the defendants' appeal and affirmed the Intermediate Court's judgment. The Higher Court's decision was final. ${ }^{150}$

\section{Zhang Chengzbi v. 21 ViaNet Communications Technology Co., Ltd.}

The plaintiff Zhang Chengzhi, author of two novels, Black Gallant Horse and North River, asserted copyright infringement against the defendant, $21 \mathrm{ViaNet}$, for storing and disseminating electronic copies of the novels online without the plaintiff's permission. ${ }^{151}$ The plaintiff brought the infringement action in the Haidian District People's Court in Beijing.

The defendant argued that it did not violate Copyright Law because the novels were uploaded by third-party users who had posted them on the defendant's website. The defendant claimed that it functioned merely as a network provider and hence could not control the content posted by others. Further, the defendant asserted that the plaintiff's two novels were also available for downloading at other Internet websites. ${ }^{152}$

The Haidian Court rejected the defendant's arguments on several grounds. ${ }^{153}$ First, the Court noted that the defendant had control over the content uploaded on their website because the defendant had a special team dedicated to digitize and store content for their novels column at the website. ${ }^{154}$ Second, the Court noted that copyright liability can be extended to cover the online dissemination of

${ }^{144} I d$.

${ }^{145} I d$.

$146 I d$.

147 Starbucks, supra note 141.

148 Id.

${ }^{149} I d$.

${ }^{150}$ Id. (the Shanghai Higher People's Ct.'s decision was rendered on Dec. 20, 2006 and both the Shanghai Interm. People's Ct. and the Higher People's Ct.'s decisions were published together in one document).

151 Zhang Chengzhi v. 21 ViaNet Commc'n Tech. Co. (Beijing First Interm. People's Ct. Dec. 17, 1999).

${ }^{152} I d$.

${ }^{153} I d$. (the lower court, the Haidian Dist. People's Ct. of Beijing, rendered its decision on Sept. 18, 1999).

${ }^{154} I d$. 
copyrighted works without permission from the copyright owner. ${ }^{155}$ Under Copyright Law, only the copyright owner has "the right of publication, the right of authorship, the right of revision, the right to protect the integrity of his work, the right to use and the right to remuneration." 156 Moreover, the Court stated that the right to use and the right to remuneration means

the right to make use of his work by way of reproduction, performance, broadcasting, exhibition, distribution, producing motion pictures, television and other audio-visual works, or through adaptation, translation, annotation, compilation, or other ways, as well as the right to authorize others to make use of his work in the above-mentioned ways and to receive remuneration for such use. ${ }^{157}$

Though the Copyright statute does not specifically mention distribution of content online, the Court found that online distribution is "essentially a way to make the content of the work known by the public."158 Accordingly, the defendant's online dissemination and distribution of the plaintiff's novels without the plaintiff's permission violated the Copyright Law. The defendant infringed on the plaintiff's right to use his copyrighted works and his right to remuneration. ${ }^{159}$

The Haidian Court issued its judgment against the defendant and ordered the defendant to cease uploading the two novels and pay the plaintiff 13,080 yuan for economic losses. ${ }^{160}$ The Court instructed the defendant to make a public apology to the plaintiff by publishing a declaration on the defendant's website homepage. The content of the public apology must be approved by the Court. If the defendant failed to issue an apology within ten days of the judgment, the Court would "draft an announcement by itself and publish it on the electronic version of a newspaper distributed throughout China, and relevant expenses should be borne" by the defendant. ${ }^{161}$

The defendant appealed the case to the Intermediate People's Court in Beijing, asserting that the existing Copyright Law does not extend liability to network content providers. ${ }^{162}$ The Intermediate Court rejected the defendant's argument and reemphasized that Copyright Law protects the copyright owner by providing the owner with exclusive rights. ${ }^{163}$ The Intermediate Court instructed that as a network content provider, the defendant has "the obligation to know whether the contents it provides on its website to the public would infringe upon other's copyrights." 164 The Intermediate Court affirmed the Haidian Court's judgment on injunction, damages and public apology. ${ }^{165}$

${ }^{155} \mathrm{Id}$.
${ }^{156} \mathrm{Id}$.
${ }^{157}$ Zhang Chengzhi, supra note 151.
${ }^{158} \mathrm{Id}$.
${ }^{159} \mathrm{Id}$.
${ }^{160} \mathrm{Id}$.
${ }^{161} \mathrm{Id}$.
${ }^{162}$ Zhang Chengzhi, supra note 151.
${ }^{163} \mathrm{Id}$.
${ }^{164} \mathrm{Id}$.
${ }^{165} \mathrm{See}$ Founder Co., Red Mansion Inst. v. Gaoshu Tianli Co. (No. 1 Interm. People's Ct. of Beijing Municipality Dec. 20, 2001), rev'd, (Higher People's Ct. of Beijing Municipality July 15, 2002, rev'd, (Sup. People's Ct.) (reinstating the damages awarded by the Interm. Court and affirming the public apology order); Ding Xiaochun v. Nantong Educ. Bureau (Interm. People's Ct. of Nantong City Dec. 19, 2002) (ordering the defendant to cease the unauthorized publication of the plaintiff's photographs, to compensate the plaintiff for economic loss, and to make a public apology in the Nantong Daily). 


\section{Beijing Baidu Netcom Science and Technology Co., Ltd. v. Tsingtao Osun Network Technique Co., Ltd., et. al.}

Baidu is the largest internet search engine site in China. In 2009, it processed visits and query searches from ten million net users per day. Baidu brought an unfair competition law suit against Osun and others for using technical means to insert defendants' advertising pages and cause them to pop-up before Baidu's normal display of search results. The defendants' pop-up advertisements appeared whenever a user logged on to Baidu's search engine site to make a key word search. Baidu brought the law suit in the Intermediate People's Court of Qingdao City. On September 2, 2009, the Intermediate Court found that the defendants' pop-up advertisement activities "made use of the search service provided by Baidu ... for their own benefits without the consent of Baidu."166 Also, the defendants' conduct was "against the will" of the internet users and caused the users to "mistake the pop-up advertising pages for something placed by Baidu."167 Consequently, the users may "downgrade their satisfaction" with Baidu's services and may have "a negative impact" on Baidu's goodwill.168

The Intermediate Court held that the defendants violated China's Anti-Unfair Competition statute. The defendants were ordered to cease their activities, pay damages and remove ill effects. Specifically, the Intermediate Court stated that since the defendants' "acts occurred on the Internet, ... the two defendants should publish statements on the homepages of their websites . . to eliminate ill effects." 169 The Court instructed that the apology statements must be subject to the court's review and be posted at the defendants' homepages for fifteen consecutive days. ${ }^{170}$ The defendants had ten days to comply with the court's order. The defendants appealed to the Higher People's Court of Shandong which affirmed the Intermediate People's Court of Qingdao City on March 20, 2010.171

In summary, the above cases illustrate that in intellectual property cases involving either unauthorized use of rights related to the author under copyright law or names or trademarks to intentionally mislead the consumer, the defendant must cease the infringing conduct, pay damages, and issue an apology. The Court retains its authority to review the content of the apology. The apology must be publicly made. As seen in the cases, the apologies were to be published in Legal Daily, a computer trade publication, and the infringer's website homepage, so all could read it. Moreover, the court orders emphasize that if the defendants fail to timely publish their apologies, the Court would draft an announcement, publicize the judgment through the relevant media, and instruct the defendants to pay the associated expenses.

\section{APOLOGY CONTEXT, CONTENT, AND PURPOSE}

Analyzing China's statutes relating to intellectual property and civil remedies and the written decisions rendered by Chinese people's courts provide a comprehensive understanding of how China attempts to right harms done to intangible and personality rights, specifically how public apologies indeed can serve as part of correcting wrongs. It is instructive to examine actual public apologies for context, content and purpose.

166 Beijing Baidu Netcom Sci. and Tech. Co. v. Tsingtao Osun Network Technique Co. (Interm. People's Ct. of Qingdao City Sept. 2, 2009) (China).

${ }_{167} I d$.

${ }_{168} \mathrm{Id}$.

${ }^{169} \mathrm{Id}$.

${ }^{170} \mathrm{Id}$.

171 Beijing Baidu Netcom Sci. and Tech. Co. v. Tsingtao Osun Network Technique Co. (Higher People's Ct. of Shandong Mar. 20, 2010) (China), aff'd (Interm. People’s Ct. of Qingdao City Sept. 2, 2009). 
Consider the following public apology statement made by China Peking Opera Theater to Mr. Ma Shaobo on August 23, 2000, after the court held that the Opera infringed on Mr. Ma's copyrights in three plays. ${ }^{172}$ The apology was published in the "Chinese Theater" publication in September 2000. It is also available online for the public to view.

Mr. Ma Shaobo, one of the founders of our Theater, while working in the leading position in the past years, devoted much time and effort in organizing the rehearsal of many high-quality plays, and participating in the writing of several plays including: "Peroxide Blonde" (Bai Mao Nu), "Inexperienced" (Chu Chu Mao Lu) and "Whole Red River" (Man Jiang Hong).

When we were compiling and printing the commemorative album to celebrate the 40th anniversary, we didn't put his signature on three plays, our conduct severely infringes his copyright.

We have sincerely accepted the judgment of Beijing No.1 Intermediate People's Court and the final judgment of Beijing Supreme Court on August 15, 2000, and are determined to correct our mistakes.

First, the documents, files, and the certifying materials based on these documents that are related to Mr. Ma Shaobo, we released in the past political movements shall all become invalid. Second, we will put his signature in the memorial album on those three plays. Third, we hereby state our apologies to Mr. Ma Shaobo, and guarantee that we will earnestly respect the writer's copyright in the future performances and publication.

Consider the next apology statement in a trademark infringement case where the defendants, the Gang Tian Motorcycles and related companies used the "Yamaha" trademark without authorization. The Tianjin Supreme People's Court rendered judgment against the defendants. Pursuant to the Court's order, the defendants made the following public apology in the Motorcycle Publication in April 2003. The apology is also available online. ${ }^{173}$

While reporting the 2009 and 2010 "National Catalog of manufacturers and products for Automobile, Civil refitted car and Motorcycle", we used "Linhai-Yamaha" as the engines' trademark, on the types of GT125T, GT125T-A, GT125T-B and GT505T-A Gang Tian Motorcycles, which has been determined as infringement on the trademark of Yamaha Motor Co., Ltd in the above-mentioned judgment. ${ }^{174}$

172 Wei Wo Yuan Qin Fan Ma Shao Bo Tong Zhi Zhu Zuo Quan Shi Xiang Ma Shao Bo Tong Zhi Dao Qian, [Apology Statement About Copyright Infringement from the Chinese Peking Opera Theater to Mr. Ma Shaobo], CHINESE THEATER (September 2000), available at http://ezlibrary.sufe.edu.cn:2067/kns50/detail.aspx?dbname =CJFD2000\&filename $=$ XIJU200009006 [hereinafter Peking Opera Apology].

173 Apology Statement, supra note 172 (The Chinese and English versions of the apology are on file with the author. A few years later, Yamaha brought another trademark infringement case against a different group of defendants and prevailed. The Chinese Supreme People's Court in Beijing ordered an injunction and awarded the largest damages in a trademark infringement case, for its time, in the amount of $\$ 8.3$ million yuan, and also instructed the defendant to make a public apology.); see Olivia Chung, A Trademark Milestone for Yamaha in China, AsiA Times OnLINE (June 29, 2007), http:/ /www.atimes.com/atimes/China_Business/IF29Cb02.html.; see also On the Judgment on Trademark Infringement Case Passed by the Supreme Court of the People's Republic of China - Upholding the 2005 Decision of the Jiangsu Higher People's Court, YAMAнA MOTOR (June 12, 2007), http://www.yamaha-motor.co.jp/global/news/2007/06/12/trademark.html (noting that the public apology must be published in “摩托车商情”[Motuoche Shangqing] magazine).

174 "The above-mentioned judgment" refers to "According to the Gao Zhi Chu Zi (2001) No. 3 Paper of Civil 
Our subordinate enterprises including: Tianjin Gang Tian Motorcycle Co., Ltd. / Tianjin Gang Tian Engine Co., Ltd. / Tianjin Gang Tian Motorcycle Sales Co., Ltd. and Tianjin Gang tian Automobile Sales Co., Ltd., used "LINHAI-YAMAHA" as the engine's trademark on the above-mentioned types of motorcycles in their production and sales, which has also been determined as infringement on the trademark of Yamaha Motor Co., Ltd in the above-mentioned paper of judgment.

The 37 GangTtian GT126-6 type motorcycles, produced by our subordinate enterprise Tianjin Gang Tian Engine Co., Ltd., used the logo "VISION". This behavior has also been determined as infringement on the trademark of Yamaha Motor Co., Ltd in the above-mentioned paper of judgment.

The GT50T-A type Gang Tian motorcycles, also produced by our subordinate enterprise Tianjin Gang Tian Engine Co., Ltd., were attached with the mark "Engine licensed by Yamaha" at the front and rear. This expression has also been determined as infringement on the trademark of Yamaha Motor Co., Ltd in the above-mentioned paper of judgment.

We hereby apologize to Yamaha Motor Co., Ltd for these trademark infringements. And we have already modified the contents related to the "Linhai-Yamaha" engines in "National Catalog of Manufacturers and products for Automobile, Civil refitted car and Motorcycle". Furthermore, we guarantee that we will not have those or similar infringing acts in the future.

The next set of apologies is from individuals and companies who infringed the registered trademark "Deli" owned by the Deli Group Ltd. The defendants used the plaintiff's "Deli" trademark on stationery products. The apologies were published together in the Wuyi Today newspaper on April 8, $2011 . .^{175}$

\section{Statement of Apology (I)}

A series of "Deli" trademarks which are registered by Deli Group Ltd. have a high recognition in the market. We (Wuyi County Ming-cheng Printing and Packing Ltd.) infringed the exclusive right of "Deli" trademark by using the trademark on the stationery products manufactured by us and thus damage the reputation of "Deli" trademark. We hereby make the following statement of apology:

1. We contribute sincere apology to Deli Group Ltd. for the losses caused by our production and selling infringing products and we are willing to compensate losses caused thereby.

2. We promise not to use any registered trademark owned by Deli Group Ltd. in the future, or we will be liable to any related infringements.

Judgment from Tianjin Supreme Court." See Tianjin Gang Tian Ji Tuan Jiu Yu Ya Ma Ha Fa Dong Ji Zhu Shi Hui She Shang Biao Qin Quan Jiu Fen An Jian de Dao Qian Sheng Ming [The Apology Statement for Trademark Infringement from Tianjin Gang Tian Group to Yamaha Motor Co., Ltd.], MOTOR CYCLE 59 (Apr. 2003), http://ezlibrary.sufe.edu.cn:2067/kns50/detail.aspx?dbname=CJFD2003\&filename=MTCI200304047 [hereinafter Gang Tian Apology].

175 Deli Trademark Apologies (the apologies in Chinese are on file with author). 
Apologizer: Wuyi County Ming-cheng Printing and Packing Ltd.

\section{$\underline{\text { Statement of Apology (II) }}$}

A series of "Deli" trademarks which are registered by Deli Group Ltd. have a high recognition in the market. I infringed the exclusive right of "Deli" trademark by using the trademark on the stationery products manufactured by us and thus damage the reputation of "Deli" trademark. I hereby make the following statement of apology:

1. I contribute sincere apology to Deli Group Ltd. for the losses caused by my production and selling infringing products and we are willing to compensate losses caused thereby.

2. I promise not to use any registered trademark owned by Deli Group Ltd. in the future, or I will be liable to any related infringements.

Apologizer: He Wei-lan

\section{$\underline{\text { Statement of Apology (III) }}$}

A series of "Deli" trademarks which are registered by Deli Group Ltd. have a high recognition in the market. I infringed the exclusive right of "Deli" trademark by using the trademark on the stationery products manufactured by us and thus damage the reputation of "Deli" trademark. I hereby make the following statement of apology:

1. I contribute sincere apology to Deli Group Ltd. for the losses caused by my production and selling infringing products and we are willing to compensate losses caused thereby.

2. I promise not to use any registered trademark owned by Deli Group Ltd. in the future, or I will be liable to any related infringements.

Apologizer: Wuyi County Tai-ji Stationery Factory Lan Xian-chang

\section{Statement of Apology (IV)}

A series of "Deli" trademarks which are registered by Deli Group Ltd. have a high recognition in the market. I infringed the exclusive right of "Deli" trademark by using the trademark on the stationery products manufactured by us and thus damage the reputation of "Deli" trademark. I hereby make the following statement of apology:

1. I contribute sincere apology to Deli Group Ltd. for the losses caused by my production and selling infringing products and we are willing to compensate losses caused thereby.

2. I promise not to use any registered trademark owned by Deli Group Ltd. in the future, or I will be liable to any related infringements. 


\section{Apologizer: Wuyi County Kai-wei Stationery Factory He Dong-xian}

\section{$\underline{\text { Statement of Apology (V) }}$}

A series of "Deli" trademarks which are registered by Deli Group Ltd. have a high recognition in the market. I infringed the exclusive right of "Deli" trademark by using the trademark on the stationery products manufactured by us and thus damage the reputation of "Deli" trademark. I hereby make the following statement of apology:

1. I contribute sincere apology to Deli Group Ltd. for the losses caused by my production and selling infringing products and we are willing to compensate losses caused thereby.

2. I promise not to use any registered trademark owned by Deli Group Ltd. in the future, or I will be liable to any related infringements.

Apologizer: Xu Zhi-xiang

The illustrative sample apologies above share several distinctive characteristics that make them effective, as discussed below.

\section{A. In Newspapers or Trade Publications}

All of the above apologies above are public and accessible. The wrongdoers announced their apologies to the plaintiffs in a public forum. Most significantly, the announcements were not oral. ${ }^{176} \mathrm{It}$ is in writing and published in a newspaper or trade publication. That means the public can read it at the time of publication and in the future. Further, in the age of digital media, the newspapers and trade publications are now available online. The public can gain access to online content and read the apologies. ${ }^{177}$ The widely available publication of the apologies serves an important role in the dissemination of the apology content in informing and educating the public. In other words, the publication of the apology, whether in a newspaper or trade publication, indicates that Chinese laws

${ }^{176}$ In the United States, as discussed by scholars, apologies seem to be mostly oral. See Erin O'Hara O'Connor, Organizational Apologies: BP as a Case Study, 64 VAND. L. REV. 1959, 1969 (2011) ("People also tend to scrutinize apologies for more subtle indicators of sincerity.... Nonverbal cues are also scrutinized, including eye contact, breathing, body posture, facial complexion, facial expressions, tone of voice, and pace of speech.”); Jennifer K. Robbennolt,_Apologies and Reasonableness: Some Implications of Psychology for Torts, 59 DEPAUL L. REV. 489, 496 (2010) ("factors such as tone of voice, non-verbal gestures, or facial expressions moderate the effects of apologies.").

${ }^{177}$ In the United States, a few reported court rulings involve apologies posted on YouTube and Facebook. For example, a court in Florida ordered teens to post their apology on YouTube. See Keyonna Summers, Judge Orders Teens to Post Apology on YouTube, USA TODAY (June 8, 2008), http://www.usatoday.com/tech/webguide/internetlife/2008-06-08-youtube_ N.htm (court ordered the teens "to post another video on YouTube: an apology that shows them face down and handcuffed on the hood of a car. The judge, prosecutor and defense attorneys who devised this punishment hope it will serve as a deterrent."). Another court ordered a divorcing man to post an apology on his Facebook. See Lisa Cornwell, Judge Orders Man to Apologize on Facebook, AssociATED Press (Feb. 24, 2012), available at http://www.huffingtonpost.com/2012/03/20/mark-byron-ordered-to-pos_n_1366691.html (judge ordered that the defendant in a domestic abuse case post an apology statement on his Facebook page for thirty days so all of his friends on Facebook could read it after the defendant had earlier posted numerous comments that were "clearly intended to be mentally abusive, harassing and annoying" to his wife and to "generate a negative and venomous response toward her from his Facebook friends"). See also Kimball Perry, Ex-Husband Gets Choice of Jail or a Facebook. Apology, USA TODAY (Feb. 23, 2012), http://www.usatoday.com/news/nation/story/2012-02-23/facebook-apology-divorce-jail/53221786/1. 
acknowledge the harms done not only to the plaintiff, but also to society. Societal harmony is important. The defendant's public and widely disseminated apology addresses the harm and restores societal harmony. ${ }^{178}$

\section{B. Recognition of the Injured Person's Rights}

In both public apologies, the wrongdoers acknowledged that the plaintiffs have the exclusive rights in the copyrights, trademarks, or names. Such acknowledgments are significant for the defendant to make an admission of infringing on the plaintiffs' rights. ${ }^{179}$ This affirmative step frames the context of the apology and shows that the apology is sincere. ${ }^{180}$ For example, in the Peking Opera apology, the Opera recognized Mr. Ma Shaobo as "one of the founders of our Theater" who had "devoted much time and efforts in organizing the rehearsal of many high-quality plays, and participating the writing of" the three plays in question. ${ }^{181}$ In the Deli trademark apologies, the individual and company wrongdoers recognized that Deli Group Ltd is the owner of a number of the "Deli" registered trademarks and the trademarks enjoy "high recognition in the market place."182

\section{Admission of Wrongs}

The wrongdoers in the sample apologies described and admitted to what they did and that their conduct was injurious to the plaintiff's exclusive rights in copyright or names. For example, in the China Peking Opera's apology to Mr. Ma Shaobo, the Opera knew that Mr. Ma was the author of the three plays and they ignored his copyright by publishing commemorative albums containing the plays without his authorship. In other words, they brazenly stole his works of authorship and stripped his identity from the plays. ${ }^{183}$ The Opera admitted that they "severely infringed" on Mr. Ma's copyright in the plays. ${ }^{184}$ Similarly, in the Deli trademark apologies, the wrongdoers admitted that they "infringed the exclusive right" of the plaintiff's "Deli" trademarks by using the marks on their stationery products "and thus damage[d] the reputation of 'Deli' trademark." 185 Likewise, in the Gang Tian apology, the wrongdoers described and admitted their wrongs in the first three paragraphs. As many scholars have observed,

178 In the United States, the restorative effects of apology have been noted by many scholars. See generally Jennifer Gerarda Brown \& Liana G.T. Wolf, The Paradox and Promise of Restorative Attorney Discipline, 12 NEV. L.J. 253, 294-95 (2012) (surveying apologies and effectiveness in restorative justice model); Daniel W. Shuman, The Role of Apology in Tort Law, 83 JUDiCATURE 180, 189 (2000) (asserting the restorative effects of apology); Jonathan Todres, Toward Healing and Restoration for All: Reframing Medical Malpractice Reform, 39 CONN. L. REV. 667, 710-12 (2006) (discussing how apologies can have a significant role in the restorative model in reforming medical malpractice). In addition, scholars have also recognized the reparative effects of apology in recent years. See generally O'Connor, supra note 176, at 1964-70 (noting the value of sincere apology and its reparative effects on individuals).

179 This is part of self-criticism, an important element of whether an apology is sincere. See Jeffrey S. Helmreich, Does "Sorry" Incriminate? Evidence, Harm and the Protection of Apology, 21 CORNELL J.L. \& PUB. POL'y 567, 602 (2012) (“Selfcriticism may be necessary for apologies to come across as sincere and so to be of some benefit to the victims.").

180 Some scholars have advanced that a sincere apology requires "a remorseful acceptance of responsibility for one's wrongful and harmful actions, the repudiation of the aspects of one's character that generated the actions, the resolve to do one's best to extirpate those aspects of one's character, and the resolve to atone or made amends." Jeffries G. Murphy, Repentance, Punishment, and Mercy, in Repentance: A Comparative Perspective 143, 147 (Amitai Etzioni \& David E. Carney eds., 1997); Mark A. Hall, Can You Trust a Doctor You Can't Sue? 54 DePaul L. REV. 303, 309 (2005) (“[W] hat injured patients most desire are candid acknowledgements of medical errors, a sincere apology that conveys genuine remorse, and constructive steps toward corrective actions.”).

181 See Peking Opera Apology, supra note 172.

182 See Deli Trademark. Apologies, supra note 175.

183 See Peking Opera Apology, supra note 172. ("When we were compiling and printing the commemorative album to celebrate the $40^{\text {th }}$ anniversary, we didn't put his signature on three plays, which severely infringes his copyright.").

${ }^{184} \mathrm{Id}$.

185 See Deli Trademark. Apologies, supra note 175. 
publicly admitting wrongs means that the wrongdoers have absolutely no excuse or justification for their conduct. 186

\section{Cease the Infringing Conduct}

Upon recognizing the injured person's right and admitting to the wrong conduct, the wrongdoers must take active steps to cease engaging in the wrongful conduct. In the sample apologies, the wrongdoers followed the court's order to stop the infringement. Specifically, in the China Peking Opera's apology, the Opera listed the steps that it would take to be in compliance with the court's order. ${ }^{187}$ The Opera promised to place Mr. Ma's name on the three plays as he is the author who created them. In the Gang Tian Apology, the defendants stated that they had already modified all the contents and products after the Court found that defendants' catalogues and products infringed on the Yamaha trademark. 188

\section{E. Apologize and Promise Not to Engage in Future Infringement}

Typically, in the last paragraph of a public apology, as seen in the sample apologies above, the wrongdoers state that "we hereby apologize" to the injured party for the wrongful conduct committed by the wrongdoers. ${ }^{189}$ For example, in the Deli trademark apologies, the wrongdoers apologized to the plaintiff "for the losses caused by" the infringing conduct. ${ }^{190}$ Most importantly, the wrongdoers promise that they will not engage in future infringement of the plaintiff's right. Similarly, in the Gang Tian apology, the wrongdoers promised that "we guarantee that we will not have those or similar infringing acts in the future." 191 Likewise, in the China Peking Opera apology, the wrongdoer stated "we . . . guarantee that we will earnestly respect the writer's copyright in the future performance and publication." 192 Also, in the Deli trademark apologies, the wrongdoers "promise not to use any registered trademark owned by Deli Group Ltd. in the future, or . . w will be liable to any related infringement." 193

\section{F. Apologies as Part of Remedies}

Most importantly, apologies are part of remedies. The remedies include injunction, damages, and apologies in the intentional infringement of copyrights and trademarks. ${ }^{194}$

In summary, the tone in the apologies is remorseful and purposeful. ${ }^{195}$ The defendants in the

186 Stephen P. Garvey, Punishment as Atonement, 46 UCLA L. REV. 1801, 1815 (1999) (noting apology represents "the wrongdoer's public expression of his repentance, whereby he openly acknowledges his wrongdoing and simultaneously disowns it”); MARTHA MinOw, BETWEEN VENGEANCE AND FORGIVENESS 114-15 (1998) (“to apologize is to declare voluntarily that one has no excuse, defense, justification, or explanation for an action.").

187 See Peking Opera Apology, supra note 172. ("First, the documents, files, and the certifying materials based on these documents that are related to Mr. Ma Shaobo, we released in the past political movements shall all become invalid. Second, we will put his signature in the memorial album on those three plays.").

188 See Gang Tian Apology, supra note 174.

189 Id.; Peking Opera Apology, supra note 172.

190 See Deli Trademark. Apologies, supra note 175.

191 See Gang Tian Apology, supra note 174.

192 See Peking Opera Apology, supra note 172.

193 See Deli Trademark Apologies, supra note 175.

194 See generally Nguyen, supra note 70.

195 Scholars have suggested that when an apology is remorseful and purposeful, it has significant value in medical malpractice cases and criminal cases. See generally Ashley A. Davenport, Forgive and Forget: Recognition of Error and Use of Apology as Preemptive Steps to ADR or Litigation in Medical Malpractice Cases, 6 PEPP. DisP. RESOL. L.J. 81, 101 (2006) (medical providers "must remember the fundamental purpose of the apology-to offer condolences and remorse for 
examples above admitted that what they did was wrong; they did not have the right to use the plaintiffs trademarks or copyrights; they infringed on the plaintiffs' rights; and they were sorry and promised not to engage in such acts against the plaintiffs again. The public nature and the wide dissemination of apologies are meaningful and sincere as the defendants accept responsibility for their specific wrongful conduct. 196 The apologies are forward-looking, as seen by the wrongdoers' promises to not engage in similar conduct in the future.

\section{FROM CHINA WITH MEANINGFUL APOLOGIES: IN ADDITION TO DAMAGES AND INJUNCTION}

Chinese statutes, court decisions, and public apologies relating to violations of trademarks, names, and copyrights suggest some useful lessons for all to ponder. Public apologies are available only when the violations are intentional and egregious. ${ }^{197}$

The apologies in Chinese intellectual property infringement cases analyzed above are obviously valuable to the intellectual property owners who were injured by the wrongdoer's conduct. The wide dissemination of public apologies in newspapers and trade publications has a positive impact on the society. Society is involved since everyone can read each apology, its context and content. In other words, the apology is not merely between the wrongdoer and the victim; it is about restoring value and harmony to society. ${ }^{198}$

Most importantly, the apology is meaningful because it is apology-plus. Chinese courts in intellectual property cases order apologies in addition to the order for damages and injunctive relief. Courts instruct the wrongdoers to cease the infringing activities and, in some cases, to destroy the infringing products. The injunctive relief is automatic upon the plaintiff having proved that the wrongdoer has infringed on the plaintiff's rights. ${ }^{199}$ The automatic grant prevents further harm to the plaintiff. The injunction also prevents society from being misled by the wrongdoer's conduct. 200

The court also orders the wrongdoer to pay a pecuniary sum to the plaintiff. The payment is for compensating the plaintiff where the plaintiff can establish economic losses caused by the defendant's

the injury or loss and to absolve the injured party and their family from any residual guilt" in order to make a proper apology); Stephanos Bibas \& Richard A. Bierschbach, Integrating Remorse and Apology into Criminal Procedure, 114 YALE L.J. 85, 145-47 (2004) (explaining the benefits of apology and remorse in criminal cases).

196 See O'Connor, supra note 176, at 1968-69 (dissecting former U.S. Senator Bob Packwood's apology as insincere because he failed to identify a specific wrongful act, "failed to take ownership of any wrongful action, and his apology therefore seemed strategic.”).

197 See generally Hebei Sanhe Fucheng Cattle Grp. Co. v. Kunming Branch of Harbin Fucheng Catering Co. (Higher People's Ct. of Yunnan Province Apr. 5, 2007) (China) (trademark infringement and unfair competition); Zhang Linying (copyright infringement); Liu Jingsheng v. Sohu Aitexin Info. Tech. (Beijing) Co. (Beijing Interm. People’s Ct. Dec. 19, 2006) (China) (copyright infringement); Founder Co., Red Mansion Inst. (copyright infringement).

198 Opinions of China's Supreme People's Court on Giving Full Play to the Functional Role of Intellectual Property Trials in Advancing the Great Development and Prosperity of Socialist Culture and Promoting Independent and Coordinated Economic Development (effective Dec. 16, 2011) (calling on all courts in intellectual property cases to "attach great importance to the accuracy of the initial judgment during the first-instance trial, ensure parties involved obtain judicial fairness as soon as possible, increase the rate of judgment acceptance and lawsuit termination, and reduce the rate of appeal so as to promote social harmony and stability.") (emphasis added).

199 See supra Part II.A.

200 See generally Tracy Thomas, Switching to Prophylactic Injunctions, 90 TEx. L. REV. 295, 303 (2012) (“All injunctive relief is aimed at preventing future harm."). For a historical perspective and an account of recent circuit splits on preliminary injunction, see generally Rachel A. Weisshaar, Hasy Shades of Winter: Resolving the Circuit Split Over Preliminary Injunctions, 65 VAND. L. REV. 1011 (2012). 
infringing conduct. ${ }^{201}$ The various Chinese intellectual property law and civil law statutes also allow courts to strip the wrongdoer of its gains from infringing activities. ${ }^{202}$ In other words, the payment made by the wrongdoer to the plaintiff helps steer the just recourse.

Both injunctive relief and damages payments are the plus in apology-plus. Chinese courts only order apology in intellectual property bad faith cases. This means that in ordinary infringement cases, courts limit the remedies to injunction and damages. ${ }^{203}$ Reserving apologies only for the more egregious cases, the court signals to everyone that an apology is issued carefully. This suggests that the apology is meaningful because it is not routinely used in all intellectual property cases. Also, the apology is meaningful when it is not used in lieu of injunctive relief and damages. The apology is therefore accorded with significance and importance. ${ }^{204}$

\section{WHAT CONGRESS CAN LEARN FROM CHINA ABOUT MEANINGFUL APOLOGIES}

Congress may choose to disregard how China provides remedies in intellectual property cases as irrelevant to U.S. slavery redress. That would be unfortunate. Apologies in Chinese intellectual property cases are effective and meaningful for several reasons. The wrongdoer acknowledged the injured person's rights, admitted its wrongs, provided no excuse or justifications for its wrongs, accepted responsibilities and promised not to commit such wrongs in the future. ${ }^{205}$ China's apologetic justice is rich in restorative effects. They are public and are widely disseminated to show the wrongdoer's humility and to educate the public. ${ }^{206}$ Moreover, China's apologetic justice is apology-plus. It is rarely used and is

201 See supra Part II.A.

202 See China's Civil Law, supra note 60; China's Anti-Unfair Competition Law, supra note 104.

203 See generally Tianjin Goubuli Grp. Co. v. Tianfengyuan Rest. (Higher People’s Ct. of Shandong Province Oct. 10, 2007) (China) (no apology issued); Nanjing Xuezhong Ciaying Co. v. Shanghai Xuezhong Caiying Co. (Interm. People's Ct. of Nanjing Municipality May 30, 2005) (China) (no apology issued).

204 In China, apologies as remedies are not limited to trademark, unfair competition, and copyright cases. See Zhonghua Ren Min Gong He Guo Jishuanji Ruanjian Baohu Tiaoli (中华人民共和国计算机软件保护条例) [Regulations on Computer Software Protection] (promulgated by the State Council, Dec. 20, 2001, effective Jan. 1, 2002) http://www.wipo.int/wipolex/en/text.jsp?file_id=181231, translated in http://www.wipo.int/wipolex/en/text.jsp? file_id=131055 (providing apology in arts. 23-24 as part of the remedies for software infringement); Opinions of the Beijing High People's Court on Several Issues Concerning the Trial of Cases Involving Computer Software Copyright Disputes (effective June 21, 1995) (interpreting Article 120 of the China's General Principles of the Civil Law that requires the software infringer to "make an apology and make a public notice in a newspaper for elimination of impact"); Notice of the Jiangsu High People's Court on Guiding Opinions of the Henan High People's Court for the Trial of Cases Involving Disputes Over Infringement of Trade Secrets (effective Mar. 2, 2005) (China) (stating that in addition to injunction, compensatory damages or statutory damages, the infringer must make "an apology" as part of "civil liabilities" that the infringer must bear).

205 Olivera Simic, Bringing "Justice" Home? Bosnians, War Criminals and the Interaction Between the Cosmopolitan and the Local, 12 GERMAN L.J. 1388, 1405 (2011) ("Without sincere apologies, and without genuine recognition of what happened, the past will continue to haunt the present and the cycle of vengeance will persist. Meaningful reconciliation requires 'justice as recognition,' justice in terms of the public acknowledgement of injustices.”).

206 A more recent case involving an injunction, damages, and apology is Baidu (Higher People's Ct. of Shandong Province, Mar. 20, 2010) (ordering in addition to injunction and damages, the defendants must publish an apology on their website for fifteen consecutive days and the content of the apology must first be approved by the Court).

In a different case involving the Apple company and the trademark "IPADS", Apple was sued by the Chinese trademark owner who has registered and used the trademark "IPADS" years before Apple began its use of "IPADS" in the United States and worldwide. The Intermediate People's Court in Shenzhen held that Apple violated the plaintiff's trademark right and ordered injunction, damages and apology against Apple. While the case was on appeal, Apple settled the trademark suit by paying $\$ 60$ million dollars. See Audrey Wozniak, Apple Pays $\$ 60$ Million for iPad Name in China, ABC NEWs (July 2, 2012), http://abcnews.go.com/blogs/business/2012/07/apple-pays-60-million-for-rights-to-ipad-namein-china/. 
only used in addition to injunctive relief and monetary payments to the injured persons. The apologies therefore have substance as compared to Congress' empty apology-apology without the accompaniment of any pluses whether a study of past wrongs, construction of commemorative sites or monetary reparation.

\section{CONCLUSION}

Congress may wish to argue that slavery redress is too complex. Congress may defensively assert that it simply cannot address proposals calling for monetary reparation, studies of slavery injustice, construction of memorials and monuments, and programs to educate the public about slavery. Certainly, it is easier to continue the tirade about China and intellectual property piracy to score some points in opinion polls. The problem remains. Congress' slavery apology statements ring hollow. Ironically, Congress may look to China's remedies for intellectual property infringement for valuable lessons. China requires that the wrongdoer who intentionally harms or infringes the intellectual property rights of another make a public apology in a newspaper or trade journal, in addition to stopping the harm and paying for compensatory damages and cost. If the wrongdoer does not timely make the public apology, the infringed party will draft and publish the public apology in the wrongdoer's name and charge the associated expenses to the wrongdoer. The public apology is in addition to, not in lieu of, injunctive relief and damages. If Congress approaches apology resolutions to slavery in a way similar to what China has done for remedies in intentional intellectual property infringements, righting wrongs in intellectual property harms and slavery harms will have something in common. 